NBER WORKING PAPER SERIES

\title{
U.S. INTERNATIONAL EQUITY INVESTMENT
}

\author{
John Ammer \\ Sara B. Holland \\ David C. Smith \\ Francis E. Warnock \\ Working Paper 17839 \\ http://www.nber.org/papers/w17839 \\ NATIONAL BUREAU OF ECONOMIC RESEARCH \\ 1050 Massachusetts Avenue \\ Cambridge, MA 02138 \\ February 2012
}

A revised version of this paper will be published in Journal of Accounting Research. Previous versions of this paper were titled "Look at Me Now: What Attracts U.S. Shareholders?" The authors thank Sandro Andrade, Mark Carey, Mihir Desai, Laura Field, Charles Hadlock, Andrew Karolyi, Christian Leuz, Ross Levine, Michelle Lowry, Darius Miller, Greg Nini, Bent Sorensen, Mark Spiegel, Michael Weisbach, an anonymous referee, and seminar participants at the 2004 EFA Meetings, 2006 AFA Meetings, Binghamton University (SUNY), College of William and Mary, European Central Bank, Federal Reserve Board, Federal Reserve System SCIEA Meetings, ISCTE Business School, Michigan State University, NYSE, Penn State University, Stockholm Institute for Financial Research, Universidad Catolica Portuguesa, Universidade do Porto, University of Houston, University of Minnesota, and University of Virginia for helpful comments. Nathanael Clinton and Alex Rothenberg provided exceptional research assistance. The views expressed in this paper are solely the responsibility of the authors and should not be interpreted as reflecting the views of the Board of Governors of the Federal Reserve System or of any other employee of the Federal Reserve System. The statistical analysis of security-level data on U.S. investors' holdings reported in this study was conducted at the International Finance Division of the Board of Governors of the Federal Reserve System under arrangements that maintained legal confidentiality requirements. Warnock thanks the Darden School Foundation for generous support. The views expressed herein are those of the authors and do not necessarily reflect the views of the National Bureau of Economic Research.

NBER working papers are circulated for discussion and comment purposes. They have not been peerreviewed or been subject to the review by the NBER Board of Directors that accompanies official NBER publications.

(C) 2012 by John Ammer, Sara B. Holland, David C. Smith, and Francis E. Warnock. All rights reserved. Short sections of text, not to exceed two paragraphs, may be quoted without explicit permission provided that full credit, including (C) notice, is given to the source. 
NBER WORKING PAPER SERIES

U.S. INTERNATIONAL EQUITY INVESTMENT

\author{
John Ammer \\ Sara B. Holland \\ David C. Smith \\ Francis E. Warnock \\ Working Paper 17839 \\ http://www.nber.org/papers/w17839
}

\author{
NATIONAL BUREAU OF ECONOMIC RESEARCH \\ 1050 Massachusetts Avenue \\ Cambridge, MA 02138 \\ February 2012
}

Previous versions of this paper were titled "Look at Me Now: What Attracts U.S. Shareholders?" The authors thank Sandro Andrade, Mark Carey, Mihir Desai, Laura Field, Charles Hadlock, Andrew Karolyi, Christian Leuz, Ross Levine, Michelle Lowry, Darius Miller, Greg Nini, Bent Sorensen, Mark Spiegel, Michael Weisbach, an anonymous referee,and seminar participants at the 2004 EFA Meetings, 2006 AFA Meetings, Binghamton University (SUNY), College of William and Mary, European Central Bank, Federal Reserve Board, Federal Reserve System SCIEA Meetings, ISCTE Business School, Michigan State University, NYSE, Penn State University, Stockholm Institute for Financial Research, Universidad Catolica Portuguesa, Universidade do Porto, University of Houston, University of Minnesota, and University of Virginia for helpful comments. Nathanael Clinton and Alex Rothenberg provided exceptional research assistance. The views expressed in this paper are solely the responsibility of the authors and should not be interpreted as reflecting the views of the Board of Governors of the Federal Reserve System or of any other employee of the Federal Reserve System. The statistical analysis of security-level data on U.S. investors' holdings reported in this study was conducted at the International Finance Division of the Board of Governors of the Federal Reserve System under arrangements that maintained legal confidentiality requirements. Warnock thanks the Darden School Foundation for generous support. The views expressed herein are those of the authors and do not necessarily reflect the views of the National Bureau of Economic Research.

NBER working papers are circulated for discussion and comment purposes. They have not been peerreviewed or been subject to the review by the NBER Board of Directors that accompanies official NBER publications.

(C) 2012 by John Ammer, Sara B. Holland, David C. Smith, and Francis E. Warnock. All rights reserved. Short sections of text, not to exceed two paragraphs, may be quoted without explicit permission provided that full credit, including $(\mathcal{C}$ notice, is given to the source. 
U.S. International Equity Investment

John Ammer, Sara B. Holland, David C. Smith, and Francis E. Warnock

NBER Working Paper No. 17839

February 2012

JEL No. F3,G11

\begin{abstract}
$\underline{\text { ABSTRACT }}$
U.S. investors are the largest group of international equity investors in the world, but to date conclusive evidence on which types of foreign firms are able to attract U.S. investment is not available. Using a comprehensive dataset of all U.S. investment in foreign equities, we find that the single most important determinant of the amount of U.S. investment a foreign firm receives is whether the firm cross-lists on a U.S. exchange. Correcting for selection biases, cross-listing leads to a doubling (or more) in U.S. investment, an impact greater than all other factors combined. We also show that our firm-level analysis has implications for country-level studies, suggesting that research investigating equity investment patterns at the country-level should include cross-listing as an endogenous control variable. We describe easy-to-implement methods for including the importance of cross-listing at the country level.
\end{abstract}

John Ammer

International Finance Division

Board of Governors of the Federal Reserve System

Washington DC 20551

john.ammer@frb.gov

Sara B. Holland

University of Georgia

Terry College of Business

sbh@uga.edu
David C. Smith

McIntire School of Commerce

University of Virginia

Charlottesville, VA 22903

dcs8f@comm.virginia.edu

Francis E. Warnock

Darden Business School

University of Virginia

Charlottesville, VA 22906-6550

and NBER

warnockf@darden.virginia.edu

An online appendix is available at:

http://www.nber.org/data-appendix/w17839 


\section{Introduction}

U.S. investors are the single largest group of international equity investors in the world. As of end-2007, U.S. international equity investment totaled $\$ 5.3$ trillion, an amount comparable to the securities holdings of all sovereign wealth funds or to the total holdings of all global reserves held by national governments. ${ }^{1}$ The past decade has witnessed a resurgent interest in studying patterns of international investment, and U.S. international equity investment figures prominently in many studies. ${ }^{2}$ Despite the size of the U.S. foreign equity portfolio and the renewed focus on international investment research, no study can point to the most important determinants of the amount of U.S. investment that a foreign firm receives.

Perhaps the largest roadblock in the literature is that, until recently, there has been no dataset that is particularly well-suited to examining U.S. equity investments abroad. Many existing studies use country-level data (e.g., U.S. investors' holdings of German equities as compared to Japanese equities), which is publicly available but naturally limited. Some studies utilize firmlevel data, but with narrow datasets (e.g., focusing on a small set of foreign countries, or limited to the portfolios of institutional investors with public disclosure obligations) or with simple methodologies that make establishing causation difficult.

In this paper we use the most comprehensive dataset available on U.S. international equity investment — a confidential security-level dataset of all U.S. investors' holdings of foreign equities used by U.S. Treasury officials to calculate foreign holdings by U.S. residents - to answer one important question: What are the most important determinants of U.S. investment in the equity of foreign firms?

\footnotetext{
${ }^{1}$ On the investments of sovereign wealth funds, see Bernstein, Lerner, and Schoar [2009].

2 See, among many others, Glassman and Riddick [2001], Dahlquist, Pinkowitz, Stulz, and Williamson [2003], Ahearne, Griever, and Warnock [2004], Chan, Covrig and Ng [2005], Fidora, Fratzscher, and Thimann [2007], Kho, Stulz, and Warnock [2009], Lane and Milesi-Ferretti [2008], Bekaert, Siegel and Wang [2012], Desai and Dharmapala [2011], Didier, Rigobon, and Schmukler [2010], Amiram and Frank [2010], and Yu [2010].
} 
To motivate this question further, consider the composition of U.S. investors' foreign equity portfolios compared to what would be implied by traditional portfolio theory. The simplest portfolio approach to international investment predicts that all investors hold portfolios with a weight on each firm that is proportional to the firm's weight in the world market portfolio. While it is well-established that U.S. investors, in aggregate, underweight foreign equities (and overweight domestic stocks) relative to simple benchmarks, our firm-level holdings data show that on a firm-by-firm basis the U.S. international equity portfolio also differs dramatically from the market portfolio weights. ${ }^{3}$ U.S. investors ignore many foreign stocks—-the median foreign firm received U.S. investment amounting to only 0.4 percent of market capitalization-and concentrate disproportionately on others. Foreign firms in the $90^{\text {th }}$ and $95^{\text {th }}$ percentiles attract U.S. investment totaling 10.7 and 16.7 percent, respectively, of their market capitalization. As it turns out, a significant proportion of these firms with heavy U.S. weights have also cross-listed on a U.S. exchange.

These observations, as well as past work that noted an association between U.S. investment and cross-listings, ${ }^{4}$ prompts us to explore the differences in U.S. holdings of crosslisted and non-cross-listed foreign firms. In fact, merely distinguishing whether or not a foreign firm cross-lists in the United States reveals a striking contrast. Median U.S. investment in crosslisted firms is 13.6 percent of the firm's market capitalization, dwarfing the 0.3 percent median holdings in non-cross-listed firms.

This stylized fact, while interesting, cannot be interpreted without reference to the

\footnotetext{
${ }^{3}$ On the home bias, see Lewis [1999], Ahearne, Griever, and Warnock [2004], and Kho, Stulz, and Warnock [2009], among many others.

${ }^{4}$ Our paper is not the first to note that cross-listing can increase U.S. investment. See, for example, Ahearne, Griever, and Warnock [2004], Bradshaw, Bushee, and Miller [2004], Edison and Warnock [2004], Aggarwal, Klapper, and Wysocki [2005], Ferreira and Matos [2008], and Kho, Stulz, and Warnock [2009]. However, due to data limitations, none of these papers can accurately measure and distinguish a cross-listing effect from potential selection biases, nor do they investigate causation.
} 
underlying causal links between cross-listing and U.S. investment. In particular, cross-listing is a voluntary decision, and it is typical for large, well-established and highly liquid firms to choose the United States as a cross-listing venue. Thus, the kinds of firms that choose to cross-list might be the types that attract substantial U.S. ownership even without the cross-listing. Moreover, these firms might choose to cross-list exactly because this attracts large U.S. investment. As we discuss below, distinguishing these effects has important economic implications. What the summary statistics do tell us is that any attempt to understand the most important factors determining which foreign firms are able to attract U.S. investment must also address the firm's decision of whether or not to cross-list on a U.S. exchange.

Because the econometrics literature suggests that there is no single statistical methodology that perfectly accounts for the endogeneity inherent in a firm's decision to cross-list, we use three complementary techniques to study the impact of selection and isolate the cross-listing effect on U.S. holdings. ${ }^{5}$ We first estimate a parametric model that explicitly accounts for the underlying endogeneity between U.S. holdings behavior and the decision to cross-list on a U.S. exchange. The model jointly estimates the cross-listing and holding decisions as a system of simultaneous equations, using a Heckman [1979]-type methodology first proposed by Lee [1978] to study the impact of union membership on wages. This framework not only allows us to adjust for the effects of selection bias, but also produces structural estimates of the relation between holdings and crosslisting. We follow the parametric results with two additional methods for selection-bias adjustment: semi-parametric propensity score matching and non-parametric "difference-indifferences" estimates.

The results from all three methodologies present a consistent and compelling picture of the

\footnotetext{
${ }^{5}$ For recent critiques and reviews of selection-bias corrections, see Lalonde [1986], Heckman, Ichimura, Smith, and Todd [1998], and Larcker and Rusticus [2010].
} 
determinants of U.S. investment in international stocks. First, we find that the selection adjustments do matter; firms with characteristics (such as size) that help attract ample U.S. investment even without the cross-listing are more likely to elect to cross-list in the United States. But more importantly, we show that a dramatic cross-listing effect remains once we control for selection bias. The firm's decision to cross-list is the single most important determinant of the amount of U.S. investment it will receive, and the act of cross-listing causes a substantial increase in U.S. investment. Adjusted for sample selection, average U.S. holdings in foreign firms that cross-list on a U.S. exchange is two to three times higher than it would have been had the firm not cross-listed in the United States.

The impact of cross-listing cannot be ignored. The cross-listing effect itself accounts for $25-35 \%$ of all U.S. investment in foreign equities, even though only $4 \%$ of foreign firms are crosslisted. ${ }^{6}$ Our estimates imply that of the $\$ 5.2$ trillion in foreign equity held by U.S. investors in 2007 , investment due to cross-listing accounted for $\$ 2$ trillion, an amount equivalent in size to all foreign exchange reserves held by China and the eurozone or to the holdings of the largest five sovereign wealth funds. A U.S. cross-listing is not the only measurable characteristic that influences U.S. portfolio choice among foreign firms; we also report evidence that among the set of non cross-listed firms U.S. investors prefer firms that are large, transparent, and liquid. However, the firm's decision of whether or not to cross-list appears to have a greater impact than all other identifiable factors combined.

We explore explanations for the cross-listing effect and show the most obvious- that trading costs for U.S. listed stocks are lower for U.S investors - cannot explain the effect. The majority of U.S. investment in foreign companies is held directly in the foreign-traded shares,

\footnotetext{
${ }^{6}$ The cross-listing effect is $8-11 \%$, depending on the methodology and sample. In our sample, the market capitalization of cross-listed firms is $\$ 3,300$ billion, so the cross-listing effect accounted for $\$ 264-\$ 363$ billion in U.S. investment, or roughly $25-35 \%$ of the $\$ 1018$ billion total U.S. portfolio investment.
} 
rather than in the corresponding American Depositary Receipts (ADRs) that are traded on U.S. exchanges. That is, the majority of U.S. investors do not even use the U.S. market to acquire foreign shares of cross-listed firms; rather, they acquire the shares in the firms' home market. Moreover, U.S. holdings in Level I ADRs experience a much smaller "Level I effect". While traded on U.S. over-the-counter markets, Level I ADRs do not afford the legal and disclosure protections of foreign firms listed on a U.S. exchange. Instead, U.S. investors seem most attracted to cross-listed firms that become more informationally transparent following the cross-listing, particularly those firms with poor accounting practices prior to listing in the United States.

Identifying the most important factor behind U.S. international equity investment could directly impact the literature on international investment. Much of the recent research on U.S. international investment (e.g., Didier, Rigobon, and Schmukler [2010], Andrade and Chhaochharia [2010], and Desai and Dharmapala [2011]) does not control for cross-listing, implicitly treating the cross-listing effect as a sample selection issue. Because we establish that causation runs from cross-listing to U.S. investment, it is important to ascertain whether failure to include the cross-listing effect could alter inferences in the current literature. ${ }^{7}$ A priori, one would expect that inferences in papers involving variables that are highly correlated with cross-listing, but that omit a measure of cross-listing in their specifications, are most likely to be altered. In the final section of the paper, we reproduce regressions from two recent country-level U.S. equity investment papers, Andrade and Chhaochharia [2010] and Desai and Dharmapala [2011]. We add a cross-listing variable to these regressions, instrumenting for potential endogeneity in the crosslisting decision, and use a dependent variable that is both adjusted for closely held shares (following Dahlquist, Pinkowitz, Stulz, and Williamson [2003] and Kho, Stulz, and Warnock [2009]) and free of a size bias (Bekaert, Siegel and Wang [2012]). With the additional cross-listing control in place,

\footnotetext{
${ }^{7}$ We thank our referee for making this suggestion.
} 
we show that the Andrade and Chhaochharia [2010] result tying U.S. equity investment in a country to the level of U.S. foreign direct investment no longer holds, while the Desai and Dharmapala [2011] results showing a shift in portfolio allocations following the lowering of U.S. dividend taxes are somewhat weakened. Our objective is not to overturn the results of these papers - indeed, we estimate regressions that differ in important ways from the ones they implemented — but simply to show that conclusions from U.S. international investment papers are sensitive to the inclusion of a cross-listing variable (and a properly constructed dependent variable).

The rest of the paper proceeds as follows. Section 2 introduces the data used in the paper. Section 3 provides simple but informative summary statistics. Section 4 describes the methodologies we use for estimating the average cross-listing effect. Section 5 reports the main firm-level results. Section 6 applies the insights from our firm-level analysis to country-level U.S. studies, and shows that including cross-listing as an endogenous explanatory variable alters some past results. Section 7 concludes.

\section{Data}

\subsection{Benchmark Survey Data}

Our investigation relies on comprehensive security-level data on U.S. holdings of foreign stocks as obtained confidentially through periodic benchmark surveys conducted jointly by the U.S. Treasury Department and the Federal Reserve Board. ${ }^{8}$ The surveys cover holdings at two distinct points in time: December 1997 and March 1994. These surveys are somewhat dated, but are the latest available; since the 1997 survey no such survey has been processed in a way that

\footnotetext{
${ }^{8}$ Griever, Lee, and Warnock [2001] provide a primer on the survey. Complete details of the 1997 survey, including forms, instructions, and data, are available from http://www.ustreas.gov/tic/fpis.html.
} 
allows the type of security-level analysis necessary to adequately assess the determinants of U.S. investment.

Each survey must be completed by all U.S. financial institutions, both within the United States and abroad, that are entrusted with the management or safekeeping of client equity holdings. Institutions covered include all U.S. custodian banks, other commercial and investment banks, mutual funds, pension funds, insurance companies, endowments, and foundations. Respondents are required to report the foreign stock holdings of all U.S. resident clients and are subject to penalty under law for noncompliance. ${ }^{9}$

The survey, designed to pick up all recorded U.S. resident portfolio holdings of foreign equities, is the source for official U.S. data on cross-border portfolio investment. ${ }^{10}$ The only portfolio investments missed by the survey are "uncountable" holdings - i.e., those that evade detection because the U.S. resident used a foreign custodian, provided a foreign home address, or instructed the custodian not to employ a U.S. sub-custodian. Federal Reserve cross-checks with non-U.S. data collectors suggest that the number of uncountable holdings is small. ${ }^{11}$

\subsection{Sample Selection}

\footnotetext{
${ }^{9}$ Custodians are the main source of information, covering 97 percent of the market value of the securities in the 1997 survey. Institutional investors report in detail on their ownership of foreign securities only if they do not entrust the safekeeping of these securities to U.S.-resident custodians. If they do use U.S.-resident custodians, institutional investors report only the names of the custodians and the amounts entrusted, information that is then used to crosscheck the security-level data submitted by custodians.

10 "Portfolio investments" exclude holdings for control purposes, defined to be individual holdings of 10 percent or more of shares outstanding. Excluding these large holdings is likely to have little impact in our sample because it is relatively uncommon for a single U.S. investor to hold more than 10 percent of a publicly traded foreign company. ${ }^{11}$ Other data sources of U.S. investor holdings are relatively limited. For example, U.S. institutional investors' holdings as reported to the SEC on Form 13(f) exclude holdings in securities that do not trade in U.S. markets and in foreign securities that underlie ADRs. Only a small fraction of publicly traded firms domiciled outside of the United States actually trade in U.S. markets (3.5 percent in 1997, according to the U.S. Treasury/Federal Reserve survey), and, as shown below, among those that do trade within U.S. borders U.S. investors hold more than half of their ownership in the underlying security, not through ADRs. Thus, Form 13(f) filings cover only a small segment of the securities available to U.S. investors and underestimate U.S. holdings in the firms covered in their sample.
} 
We include in our investigation U.S. holdings of all non-U.S. companies tracked by Worldscope. We use the May 1999 release of Worldscope, which contains 1997 financial and accounting data on 13,445 non-U.S. companies domiciled in 52 different countries.

Dahlquist, Pinkowitz, Stulz, and Williamson [2003] and Kho, Stulz, and Warnock [2009] argue that float-adjusted measures of holdings provide a better sense of stock available for purchase by dispersed portfolio investors who have no inside connection to the firm. Thus, where possible we normalize firm-level U.S. holdings by "float", defined to be market capitalization net of the value of holdings by insiders, which requires data on both market capitalization (market value of equity) and insider holdings. Datastream, which provides the broadest international coverage of market price data, is our primary source for firm-level market capitalizations. When a value is missing in Datastream, we turn to reports from Morgan Stanley, which provide reliable market data for companies included in the MSCI All-country World index, or Worldscope, which provides December market capitalizations for those companies that complete their fiscal year at the calendar year-end. We also use Morgan Stanley and Worldscope to cross-check the Datastream numbers for recording errors. In total, we are able to calculate market capitalization figures for 12,236 of the original 13,445 Worldscope firms. Because of obvious data errors we discard 15 very small firms for which the reported value of U.S. holdings exceeds reported stock market capitalization. The remaining sample of 12,221 firms spans 46 home countries, as listed in Table 1. To get to float, we scale market capitalization down by the figure given in Worldscope's "closely held share" field, which reports the fraction of equity owned by corporate officers, directors and their family members, individual shareholders with more than 5 percent holdings, other corporations, and the firm's own pension funds and trusts. We adjust these Worldscope figures to exclude the value of depositary institution holdings, which are sometimes mistakenly 
counted in the closely held fields. ${ }^{12}$ Because of missing data on insider holdings, our float-adjusted sample contains 8,528 firms. Note, too, that accurate firm-level data on float are largely unavailable for our 1994 sample, so when we analyze that sample we scale holdings by market capitalization.

Our sample is quite representative. The 12,221 firms for which we could match Worldscope and U.S. holdings data had an end-1997 market capitalization of \$11,079 billion, representing more than 90 percent of the value of all non-U.S. equity (International Finance Corporation [1998]). U.S. investors' \$1,018 billion stake in these companies accounted for over 92 percent of the $\$ 1,208$ billion total U.S. foreign equity holdings. Most of the $\$ 90$ billion in U.S. holdings omitted (by necessity) from our sample are in firms located in the Caribbean financial centers, for which firm-level variables are generally unavailable.

\section{Summary Statistics}

\subsection{U.S. holdings across all foreign firms}

Table 2 reports the distribution of U.S. holdings of non-U.S. firms as of December 1997. As a benchmark, note that if U.S. investors followed a simple portfolio model in which the weight of each firm in U.S. portfolios equaled its weight in the "world market portfolio", U.S. holdings would amount to 49.6 percent of the market capitalization (58.3 percent of float) of each foreign firm.

The table shows that firm-level U.S. holdings differ dramatically from the world market

\footnotetext{
${ }^{12}$ Specifically, we exclude holdings by the Bank of New York, Morgan Guaranty Trust, and Citibank, because these shares are likely to be holdings for ADR programs, and the New Zealand Central Securities Depositary. There are other reasons to believe that the Worldscope measure of insider holdings contains measurement error. Worldscope coverage of the "closely held shares" field is uneven, and reporting requirements differ across countries. Moreover, it is unclear whether the classifications within Worldscope of what constitutes a closely held share conform well to theory on who gains private benefits from control and who would be willing to sell to a U.S. investor. For example, the measure includes holdings of large, unaffiliated blockholders.
} 
portfolio. Mean U.S. holdings are 3.5 percent of foreign firms' market capitalization (6.3 percent of float). This substantial underinvestment relative to the world market portfolio is, of course, one representation of the home bias. While the home bias is well-established, the extent of the underinvestment is striking, with fully one-quarter of all foreign firms receiving no U.S. investment at all, and median U.S. investment equivalent to only 0.4 percent of market capitalization (1.2 percent of float). However, the figures for the $90^{\text {th }}$ and $95^{\text {th }}$ percentiles show that holdings in these less popular firms are offset by a significant minority of international companies in which U.S. investors own 10 percent or more of the market capitalization and at least 20 percent of the outstanding float.

In other words, the aggregate foreign equity portfolio of a very large, diverse, and quantitatively significant group of investors appears to deviate quite sharply from market weights. This fact seems particularly surprising given that much of this investment is directed by professional managers whose performance tends to be measured against broad market benchmarks. It is also at odds with the notion that U.S. investors, were they relatively uninformed outsiders, ought to take a passive approach to portfolio choice in foreign equities.

\subsection{U.S. holdings and cross-listing}

Why do some foreign firms receive so much more U.S. investment than others? What is the most important determinant of the extent of U.S. investment a foreign firm receives? As a first pass at answering these questions, we reexamine the distribution of U.S. holdings, but this time we split the sample by whether a firm is cross-listed on a U.S. exchange (Table 3). ${ }^{13}$ The summary

\footnotetext{
${ }^{13}$ Most cross-listed firms in the U.S. do so via an ADR, a traded financial claim backed by a set number of equity shares in the underlying company. ADRs are created when a firm initiates a relationship with a broker that buys the firm's shares and instructs a U.S. financial institution, called a "depositary," to hold the shares in custody and issue
} 
statistics reveal a striking pattern. The vast majority of non-U.S. firms are not cross-listed on a U.S. exchange, so the distribution of U.S. holdings for the non-cross-listed sample closely resembles that of the full sample. In contrast, the summary statistics for cross-listed foreign firms are dramatically different. U.S. investors hold substantial stakes in almost all cross-listed firms. The median cross-listed foreign firm receives U.S. investment totaling 13.6 percent of market capitalization (20.2 percent of float), while the $90^{\text {th }}$ percentile cross-listed firm has almost 40 percent U.S. ownership (and over 50 percent of float).

Taken at face value, these results suggest that a U.S. cross-listing is an important determinant of the extent to which U.S. investors hold shares in a foreign firm. Whether selection can explain this large difference-in that those firms that cross-list in the United States are those that U.S. investors would prefer to hold anyway — or whether this difference is due to a true "cross-listing effect" is the key question that we address in the following sections.

\section{Methodology: Controlling for Selectivity}

Selection biases arise when a researcher attempts to compare two different population groups as if they are similar. The problem commonly occurs when heterogeneous participants selfselect into groups rather than are randomly assigned to the groups. We cannot observe the amount U.S. investors would have held in cross-listed firms in December of 1997 if those firms had not cross-listed, nor can we directly observe the reasons why the foreign firms decided to cross-list in the United States. Simple estimates of the relation between U.S. investment in foreign firms and cross-listing will be biased if the firm's propensity to cross-list on a U.S. exchange is correlated with other characteristics of the firm that affect U.S. investors' holding decisions. Moreover, firms

negotiable securities backed by the shares, the "receipts," to an interested investor. Level I ADRs trade OTC, while the "cross-listed" Level II and III ADRs list and trade on one of the major U.S. stock exchanges. 
might cross-list in the United States for the specific purpose of increasing U.S. investor interest, in which case the causation between cross-listing and U.S. holdings could run in both directions.

Our goal in determining whether there is an actual "cross-listing effect" is to estimate the unobservable component of what U.S. holdings would have been in cross-listed firms had they not cross-listed. Then, the cross-listing effect is an estimate of the treatment effect

$$
\mathrm{E}\left(\mathrm{H}_{\mathrm{i}}^{\mathrm{L}} \mid \mathrm{X}=1\right)-\mathrm{E}\left(\mathrm{H}_{\mathrm{i}}^{\mathrm{L}} \mid \mathrm{X}=0\right) \text {, }
$$

where $\mathrm{X}$ is an indicator variable set to one when a firm has cross-listed on a U.S. exchange, $\mathrm{E}\left(\mathrm{H}_{\mathrm{i}}^{\mathrm{L}} \mid \mathrm{X}=1\right)$ is the expected level of U.S. holdings in cross-listed firm $i$ conditional on it being listed, and $\mathrm{E}\left(\mathrm{H}_{\mathrm{i}}^{\mathrm{L}} \mid \mathrm{X}=0\right)$ is the expected level of holdings in cross-listed firm $i$ if it had not crosslisted. ${ }^{14}$

Corrections for selection bias are themselves subject to specification error (Lalonde [1986]; Heckman, Ichimura, Smith, and Todd [1998]; Larcker and Rusticus [2010]). Therefore, while we motivate much of our analysis of holdings and cross-listing using fully parameterized structural models of the holdings and cross-listing decisions, we ultimately incorporate three different estimators - a structural model, p-matching, and difference-in-differences - to robustly measure the cross-listing effect. We first describe the structural model, and then turn to the more general estimation of the cross-listing effect.

\subsection{Modeling the holdings and cross-listing decisions: a structural framework}

Our first estimator adopts the structural framework in Lee's [1978] study of unionization and wages, which extends the Heckman [1979] selection-bias correction to a simultaneous system.

\footnotetext{
${ }^{14}$ One could also estimate the listing impact from the non cross-listed firms, $E\left(H_{U} \mid X=1\right)-E\left(H_{U} \mid X=0\right)$, or from both cross-listed and non cross-listed firms to generate an unconditional listing impact, $\mathrm{E}(\mathrm{H} \mid \mathrm{X}=1)-\mathrm{E}(\mathrm{H} \mid \mathrm{X}=0)$. Heckman, Ichimura, Smith, and Todd [1998] provide an overview of issues relating to the different measures.
} 
In our application, the framework allows feedback from bias-adjusted holdings equations to the cross-listing decision.

\subsubsection{U.S. investors' preferences for foreign equities}

The system begins with a model of U.S investor preferences for holding foreign equity:

$$
\begin{aligned}
& H_{i}^{U}=\alpha_{U}+\mathbf{Z}_{\mathbf{i}}^{\mathbf{H}} \boldsymbol{\beta}_{\mathbf{U}}+\varepsilon_{i}^{U} . \\
& H_{i}^{L}=\alpha_{L}+\mathbf{Z}_{\mathbf{i}}^{\mathbf{H}} \boldsymbol{\beta}_{\mathbf{L}}+\varepsilon_{i}^{L}
\end{aligned}
$$

We use the same set of determinants $\left(\mathbf{Z}_{\mathbf{i}}^{\mathbf{H}}\right)$ to model both U.S. holdings of non-cross-listed stocks $\left(\mathbf{H}_{\mathbf{i}}^{\mathrm{U}}\right)$ and holdings in cross-listed stocks $\left(\mathbf{H}_{\mathbf{i}}^{\mathrm{L}}\right)$, but we place no restrictions on the coefficients, recognizing that decisions to hold these two types of stocks may be fundamentally different. This not only provides more flexibility in estimation, but also can help identify the structural parameters. Note that observations of $\mathbf{H}_{\mathrm{i}}^{\mathrm{L}}$ are $\mathbf{H}_{\mathrm{i}}^{\mathrm{U}}$ are truncated by selection because, at a given point in time, we can only observe a firm as cross-listed or not.

The instrument set $\mathbf{Z}_{\mathbf{i}}^{\mathbf{H}}$ contains firm- and country-level proxies for a variety of factors that could influence the willingness of U.S. investors to invest in a foreign firm. We motivate the contents of this instrument set in the following paragraphs. Appendix A contains specific definitions for each variable.

U.S investors may want information — both simple and more fundamental—about a foreign stock before deciding to purchase it. Firm size is a natural variable to include; larger firms are generally believed to be more transparent than smaller firms, in part because they tend to get more coverage both from the press and from securities analysts. Because measures of size are not consistent across industries - there is, in particular, a disconnect between size measures for financial services firms and firms in other sectors - we measure size using a combination of 
average industry market capitalization and the firm's size (assets) relative to its industry average. We also include an MSCI member dummy; MSCI index members are selected on the basis of liquidity, size, and market representation. Illiquidity can reflect asymmetric information (e.g., Easley and O'Hara [2004]) that would put U.S. investors at a disadvantage.

The quality or relevance of information about a foreign company will depend on, among other things, the accounting and disclosure practices of the company. Therefore, U.S. investors may favor companies that provide an accurate and timely accounting of their financial performance (Leuz and Verrecchia [2004]; Bradshaw, Bushee, and Miller [2004]), and may be attracted to foreign stocks domiciled in countries with forthright accounting practices (Lang, Lins, and Miller [2003]). Thus, we include two measures of accounting quality. The first measure is the national accounting quality index compiled by the Center for Financial Analysis and Research (CIFAR). As reported by Bushman, Piotroski, and Smith [2004], the index averages across firms within a given country the number of items, out of a possible maximum of 90 , that are included as part of a firm's financial statements. The second measure is a firm-level accounting quality index, constructed as the sum of four indicator criteria based on whether the firm uses a Big Six auditor, received a clean audit report, used international accounting standards or U.S. GAAP, and reported consolidated statements. This variable measures variation in firm-specific accounting quality not picked up by the national accounting quality variable.

U.S. investors may care about the safety of their investment in the hands of managers who operate outside U.S. borders. LaPorta, Lopez-de-Silanes, Shleifer, and Vishny (LLSV [1999], [2002]) document substantial cross-country variation in how well legal systems protect outside shareholders from expropriation by firm insiders. Durnev and Kim [2005], among others, show that the quality of corporate governance within a country can vary greatly across firms. Thus, U.S. 
investors could tilt their investments toward countries with strong legal protections of minority investors and seek out firms with a reputation for good corporate governance. We consider two measures that capture governance/legality issues: the country's LLSV shareholder rights index and a dummy for dividend-paying firms. U.S. investors may choose to underweight firms from markets with weak protections of minority shareholders. ${ }^{15}$ A company's dividend-paying record can be viewed as a commitment device, with the willingness to dispense cash signaling a commitment not to expropriate funds from minority shareholders. ${ }^{16}$ A dividend-payment dummy also helps control for a variable that cannot be included in float-adjusted regressions because it would induce measurement bias: the proportion of shares held by insiders. ${ }^{17}$

Both instrument sets also include some more general control variables. We include a country's dividend tax withholding rate faced by U.S. investors. Withholding taxes can cause U.S. investors to face higher tax rates on dividends originating from a given foreign country than on U.S. stock dividends. This would make stocks from the foreign country less attractive to U.S. investors, particularly if other potential investors in stocks from the two countries did not face the same tax rate differential (otherwise, prices could adjust to equilibrate after-tax expected returns).

${ }^{15}$ See La Porta, Lopez-de-Silanes, Shleifer, and Vishny [1998].

${ }^{16}$ See Faccio, Lang, and Young [2001], Kalcheva and Lins [2007], Pinkowitz, Stulz, and Williamson [2006], Easterbrook [1984], and Jensen [1986].

${ }^{17}$ Kalcheva and Lins [2007] provide evidence of the link between dividend payments and potential expropriation by insiders. Evidence that outside investors avoid ownership in closely held companies, perhaps fearing the power of insiders to expropriate firm resources at the expense of minority shareholders, is provided in La Porta, Lopez-deSilanes, Shleifer, and Vishny [1999], Johnson, La Porta, Lopez-de-Silanes, and Shleifer [2000], and Leuz, Lins, and Warnock [2009]. To see the bias if a closely held variable was included in our float-adjusted regressions, let $\hat{F}_{i}$ represent our market-float adjusted holdings, $\hat{U}_{i}$ represent the market capitalization (unadjusted) holdings, and $\hat{I}_{i}$ be our measurement of the proportion of shares held by insiders. Then, by definition, $\hat{F}_{i}=\frac{\hat{U}_{i}}{1-\hat{I}_{i}}$.

Suppose that the insider stake is measured with some error so that $\hat{I}_{i}=I_{i}+\eta_{i}$, where $\mathrm{I}_{\mathrm{i}}$ is the insiders' true stake and $\eta_{\mathrm{i}}$ is some white-noise error. Then, $\operatorname{cov}\left(\hat{F}_{i}-F_{i}, \hat{I}_{i}-I_{i}\right)>0$. In other words, measurement error in the proportion of insider holdings imparts a positive bias on the coefficient estimate in the holdings model when scaled by market float. Intuitively, a positive measurement error shock increase the right-hand-side variable (measured proportion of shares held by insiders) as it also increases the dependent variable (holdings, by reducing the denominator). 
Often a U.S. investor can obtain a tax credit that fully offsets a dividend tax that has been withheld by a foreign government. However, U.S. pension funds are not taxed directly on dividends, so tax credits are of no use to them, and thus taxes charged on foreign dividends generally will represent a differential between the foreign and domestic dividend tax rates that U.S. pensions face (the domestic rate is zero). Thus, at least one important investor group is clearly affected by dividend withholding tax rates.

As a measure of economic proximity (Sarkissian and Schill [2004]), we include the share of imports in total U.S. supply at the industry level. Greater economic proximity may increase familiarity and improve the flow of information. We also include in $\mathbf{Z}_{\mathbf{i}}^{\mathbf{H}}$ a dummy variable for

firms that might be fundamentally different. For example, we include a dummy for Canadian firms for two reasons. Institutional similarities and ties within North America may make Canadian firms special. In addition, for cross-listed stocks, SEC disclosure requirements are different for firms based in Canada than for those from other countries, which could affect their relative transparency to U.S. investors, all else equal.

\subsubsection{Firms' decisions to cross-list}

The second part of the simultaneous system involves a firm's decision to cross-list on a U.S. exchange. We motivate the decision by considering the potential benefits and costs of crosslisting. Let $\mathrm{X}_{\mathrm{i}}^{*}$ represent the net benefits that flow to firm $i$ from cross-listing on a U.S exchange. We assume that these benefits can be described by the following relation,

$$
\mathrm{X}_{\mathrm{i}}^{*}=\alpha_{\mathrm{x}}+\gamma_{0}\left[\mathrm{H}_{\mathrm{i}}^{\mathrm{L}}-\mathrm{H}_{\mathrm{i}}^{\mathrm{U}}\right]+\gamma_{1} \mathrm{H}_{\mathrm{i}}^{\mathrm{U}}+\mathrm{Z}_{\mathrm{i}}^{\mathrm{X}} \beta_{\mathrm{x}}-\varepsilon_{\mathrm{i}}^{\mathrm{X}},
$$

where $\mathrm{H}_{\mathrm{i}}^{\mathrm{L}}$ and $\mathrm{H}_{\mathrm{i}}^{\mathrm{U}}$ are the endogenously determined proportion of firm $i$ 's equity that would be held by U.S. investors if the firm were cross-listed (L) in the United States or not cross-listed (U), respectively. 
The difference $\mathrm{H}_{\mathrm{i}}^{\mathrm{L}}-\mathrm{H}_{\mathrm{i}}^{\mathrm{U}}$ models the anticipated impact of listing on U.S. holdings. It is included in (4) to allow for foreign firms to cross-list in the United States precisely because it attracts greater U.S. investor interest. $\mathrm{H}_{\mathrm{i}}^{\mathrm{U}}$ also enters equation (4) independently to allow the level of U.S. holdings prior to cross-listing to affect a firm's decision to cross-list. We posit that firms with large pre-existing U.S. shareholdings could cross-list on a U.S. exchange to reduce trading costs for their shareholder base.

The vector $\mathbf{Z}_{\mathrm{i}}^{\mathbf{x}}$ contains firm- and country-specific variables that are associated with benefits and costs of cross-listing, but that are taken to be exogenous. There are both direct and indirect costs associated with listing in the United States that could make firms reluctant to crosslist. Most cross-listed firms face a host of direct registration, disclosure, and compliance costs. They must register with the U.S. Securities and Exchange Commission (SEC) and submit periodic filings that are in English and include financial statements reconciled to U.S. generally accepted accounting principles (GAAP). They must meet the listing requirements of the U.S. exchange, which are often stricter than those in the firms' home country, and pay both listing fees to the exchange and filing fees to the SEC. Firms that cross-list to raise new capital must also register their securities under the SEC 1933 Securities Act and the 1934 Exchange Act. Indirect costs include the commitments that cross-listed firms make to abide by U.S. regulations and law. Firms that violate exchange regulations risk fines and the threat of delisting. Those that violate SEC regulations face potential shareholder lawsuits and civil or criminal penalties under U.S. law. Closely held firms may be especially reluctant to cross-list if the increased level of disclosure and legal oversight gives more power to minority shareholders.

The benefits of cross-listing vary across firms and can include product market considerations (to the extent that listing on the NYSE can help make a foreign company a 
household name in the United States), employee compensation (to the extent that it includes grants of options or stock), and takeover strategy (where a cross-listed stock can serve as a takeover currency). One potential benefit that both practitioners and theorists cite as a reason for crosslisting is to increase the set of investors that can, at low cost, access information and trade shares in the firm. That is, cross-listing reduces "receiver" costs associated with expanding the shareholder base (Merton [1987]]. ${ }^{18}$ This in turn may improve risk sharing, pricing, and the liquidity of a firm's stock. Accordingly, firms seeking to expand their shareholder base through increased U.S. ownership might have the strongest incentive to cross-list. Firms may also list in the U.S. to reduce institutional frictions associated with maintaining their existing investor base. For example, if a firm already has U.S. investors, it may cross-list to make it easier for those investors to manage their stock portfolios. But the other considerations (product market, compensation, takeover currency) might be more important: Any consideration that involves expanding the shareholder base must be weighed against that of relinquishing any private benefits of control.

We also include some of the variables from $\mathbf{Z}_{\mathbf{i}}^{\mathrm{H}}$, as these variables are also likely to influence the cross-listing decision. Firm size will be important for the listing decision if there are economies of scale in the direct costs of listing, including regulatory compliance and accounting disclosure. Cross-listing may be less costly for firms in industries with greater economic proximity. We include the Canada dummy because cross-listing should be less costly for Canadian

\footnotetext{
${ }^{18}$ Lang, Lins, and Miller [2003] argue that foreign firms may cross-list simply to expand their "shareholder base", the set of investors available to purchase a given firms' shares. See also Merton [1987], Miller [1999], Foerster and Karolyi [1999], Karolyi and Stulz [2003], and Doidge, Karolyi, and Stulz [2004]. The argument is also popular among U.S. practitioners who encourage foreign clients to cross-list. See Fanto and Karmel [1997], and the ADR websites at JPMorgan (www.adr.com/research/about types.html) and the Bank of New York (www.adrbny.com).
} 
firms, as they enjoy an exemption from most SEC reporting requirements. ${ }^{19} \mathrm{We}$ also posit that firms from countries with weak accounting standards will find it more costly to prepare financial statements in accordance with U.S. GAAP.

In addition, we include three variables that are unique to the cross-listing specification: home-country trading volume/GDP (because the benefits from cross-listing might be particularly high for firms that quickly "outgrow" their underdeveloped home equity markets), a Civil Law dummy (following Doidge, Karolyi, and Stulz [2004]), and the proportion of shares held by insiders (which proxies for the cost of relinquishing private control benefits through increased disclosure and monitoring associated with cross-listing). ${ }^{20}$

\subsubsection{Closing the structural model}

We do not observe $\mathrm{X}_{\mathrm{i}}^{*}$ in equation (4). Instead, we observe realizations of the indicator variable $\mathrm{X}_{\mathrm{i}}$

$$
\begin{aligned}
& X_{i}=0 \text { if } X_{i}^{*}<0 \\
& X_{i}=1 \text { if } X_{i}^{*} \geq 0 .
\end{aligned}
$$

$\mathrm{X}_{\mathrm{i}}$ equals one when firm $i$ is cross-listed on a U.S. exchange, and zero otherwise. Note that equations (4)-(6), coupled with an assumption that the error term $\varepsilon_{\mathrm{i}}^{\mathrm{X}}$ is normally distributed, imply that the listing decision can be estimated using a probit model.

Taking into account selectivity adjustments, U.S investor preferences for holding crosslisted and non-cross-listed stocks become:

\footnotetext{
${ }^{19}$ Under the Multi-Jurisdictional Disclosure System (MJDS) agreement between the SEC and the Canadian Securities Administration, Canadian firms can cross-list on a U.S. exchange without conforming to U.S. GAAP and with only minimal reporting to the SEC.

${ }^{20}$ Importantly, identification in the structural model depends on some variables directly determining one of the two endogenous variables, but not the other. Structural models can be criticized for imposing too much structure, which is one reason we also use semi- and non-parametric techniques, described below.
} 


$$
H_{i}^{L}=\alpha_{L}+Z_{i}^{H} \beta_{L}-\frac{\varphi\left(\hat{\alpha}_{R}+Z_{i}^{R} \hat{\beta}_{R}\right)}{\Phi\left(\hat{\alpha}_{R}+Z_{i}^{R} \hat{\beta}_{R}\right)} \lambda_{L}+\eta_{i}^{L}
$$

and

$$
H_{i}^{U}=\alpha_{U}+Z_{i}^{H} \beta_{U}+\frac{\varphi\left(\hat{\alpha}_{R}+Z_{i}^{R} \hat{\beta}_{R}\right)}{1-\Phi\left(\hat{\alpha}_{R}+Z_{i}^{R} \hat{\beta}_{R}\right)} \lambda_{U}+\eta_{i}^{U}
$$

Now $\mathrm{H}_{\mathrm{i}}^{\mathrm{L}}$ and $\mathrm{H}_{\mathrm{i}}^{\mathrm{U}}$ take on the additional interpretation of being the estimated holdings in firm $i$ when the firm is cross-listed and when it is not, while and $\Phi$ denote the probability density and cumulative density functions of the standard normal distribution. Equations (4), (7), and (8) now constitute a system of equations that can be estimated with maximum likelihood techniques. The estimation procedure is discussed in Appendix B. We note here only that the coefficient on $\lambda_{\mathrm{L}}$ in (7) is the inverse Mills ratio, which forms the basis for standard corrections for selectivity bias when inclusion in an estimation sample is contingent on a discrete outcome (see Heckman [1979] or Maddala [1983]), while the coefficient on $\lambda_{U}$ in (8) is a similar but less frequently used correction for selectivity bias for the non-selected observations.

Importantly, the estimates $\hat{\alpha}_{L}, \hat{\beta}_{L}$ and $\hat{\alpha}_{U}, \hat{\beta}_{U}$ from (7) and (8) are used to calculate fitted values $\hat{H}_{\mathrm{i}}^{\mathrm{L}}$ and $\hat{\mathrm{H}}_{\mathrm{i}}^{\mathrm{U}}$, which can then be plugged into the structural probit specification, (4). Because $\mathrm{H}_{\mathrm{i}}^{\mathrm{L}}$ and $\mathrm{H}_{\mathrm{i}}^{\mathrm{U}}$ are scaled (by market capitalization or market float) to only take on values between zero and one, we work off of transformations of equations (7) and (8). These transformations, along with other details of the estimation process, are described in the appendix.

\subsection{Methodologies to measure the cross-listing effect}

One of our primary interests is measuring the magnitude of the cross-listing effect, defined 
by equation (1) and reproduced here:

$$
\mathrm{E}\left(\mathrm{H}_{\mathrm{i}}^{\mathrm{L}} \mid \mathrm{X}=1\right)-\mathrm{E}\left(\mathrm{H}_{\mathrm{i}}^{\mathrm{L}} \mid \mathrm{X}=0\right) \text {. }
$$

Consistent estimation of (1) and, thus, the cross-listing effect, involves averaging across firms the difference between U.S. holdings in the firm and estimates of what the counterfactual holdings in the cross-listed firms would have been had the firm not cross-listed. Since the first component of (1), $E\left(H_{i}^{L} \mid X=1\right)$, can be estimated as the average the observed holdings in cross-listed firms, we only have to estimate the unobservable second component, $\mathrm{E}\left(\mathrm{H}_{\mathrm{i}}^{\mathrm{L}} \mid \mathrm{X}=0\right)$.

Because no method is perfect, we consider three methodologies for estimating the unobservable component. The first estimator derives from the structural model from the previous subsection. We estimate $\mathrm{E}\left(\mathrm{H}_{\mathrm{i}}^{\mathrm{L}} \mid \mathrm{X}=0\right)$ by estimating the fitted holdings from equation (8) for each firm, and then averaging over the resulting fitted holdings.

The second estimator uses the propensity-score method of matching, also termed "pmatching," originally developed by Rosenbaum and Rubin [1983]. ${ }^{21}$ P-matching uses fitted crosslisting probabilities ("propensity scores") generated from estimates of equation (4) to match each cross-listed firm with a non cross-listed firm. ${ }^{22}$ The idea is that the holdings of p-matched noncross-listed firms are likely to be similar to what a listed firm's holdings would have been if unlisted, so the average holdings of $\mathrm{p}$-matched firms can be used to estimate $\mathrm{E}\left(\mathrm{H}_{\mathrm{i}}^{\mathrm{L}} \mid \mathrm{X}=0\right)$. The advantage of the p-matching estimator is that it requires no explicit model of holdings, which reduces the risk of specification error (Drake [1993]; Dehejia and Wahba [2002]; and Zhao [2004]). The estimator has also been shown to outperform Lee/Heckman-style corrections in experimental studies of selection bias (Glazerman, Levy, and Myers [2003]). One drawback to the

\footnotetext{
${ }^{21}$ See Imbens [2004] and Stuart [2004] for recent reviews of matching applications to treatment effect estimators.

${ }^{22}$ The asymmetry in our data makes p-matching a particularly attractive method because we have a large set of firms from which to select a match (roughly 30 non cross-listed firms for each of our cross-listed firms).
} 
p-matching estimator is that it does not account for unobserved correlation between the holdings and cross-listing decisions.

We generate our third estimate of the average cross-listing effect using the "difference-indifferences" estimator (Heckman and Robb [1985]; Heckman, LaLonde, and Smith [1999]). This estimator requires holdings observations on cross-listed firms prior to their cross-listing. For this, we draw upon U.S. holdings data from the earlier March 31, 1994 survey. The difference-indifferences estimator compares the change in holdings of a firm that was not cross-listed in 1994 but cross-listed by 1997 to firms that remained non cross-listed between 1994 and 1997. That is, the cross-listing effect is given by

$$
\mathrm{E}\left(\mathrm{H}_{\mathrm{i}}^{\mathrm{L}} \mid \mathrm{X}=1\right)-\mathrm{E}\left(\mathrm{H}_{\mathrm{i}}^{\mathrm{L}} \mid \mathrm{X}=0\right)=\left(\overline{\mathrm{H}}_{\mathrm{i}}^{\mathrm{L}, 1997}-\overline{\mathrm{H}}_{\mathrm{i}}^{\mathrm{U}, 1994}\right)-\left(\overline{\mathrm{H}}_{\mathrm{j}}^{\mathrm{U}, 1997}-\overline{\mathrm{H}}_{\mathrm{j}}^{\mathrm{U}, 1994}\right),
$$

where $i$ indexes a firm that cross-lists between the 1994 and 1997 surveys, $j$ indexes a firm that remains non cross-listed in both surveys, and bars over the variables reflect sample means across the $i$ and $j$ categories. The difference-in-differences estimator incorporates many of the advantages of the p-matching estimator. Moreover, unlike the p-matching estimator, the difference-indifferences estimator accounts for unobservable components of selection bias, assuming that the characteristics of a type- $i$ firm do not change in a way that is left uncontrolled by the type- $j$ firms. ${ }^{23}$ For our application, the key drawback of the difference-in-differences estimator is that it relies on a relatively narrow subset of 132 firms that were traded only in their home market in 1994, but cross-listed by $1997 .^{24}$

\footnotetext{
${ }^{23}$ Heckman, Ichimura, Todd, and Smith [1998] provide experimental evidence that difference-in-differences estimators outperform both standard Heckman [1979] corrections and p-matching estimators.

${ }^{24}$ Because the sample size would be reduced to an even greater extent by requiring insider holdings information for 1994 and we have no way of correcting mistakes in 1994 insider holdings data, we do not report difference-indifferences estimates using the market float measure.
} 


\section{Results}

\subsection{Results from the structural model}

Table 4 reports estimates of our structural model of cross-listing and U.S. holdings as of end-1997 scaled by float. ${ }^{25}$ Results using holdings scaled by market capitalization (not shown, but available from the authors) are not materially different. Requiring a complete set of explanatory variables for the Heckman [1979]-based and p-matching estimators reduces our sample to 8,086 firms, 282 of which cross-listed on a U.S. exchange.

\subsubsection{Determinants of holdings in firms that are not cross-listed}

While our focus is on the cross-listing effect, and holding of non cross-listed firms are quite small (median holdings are 1 percent of float), it is nonetheless informative to understand the factors behind U.S. investment in firms that are not cross-listed. Among the 7,804 firms that are not cross-listed (the middle column in Table 4), all of the explanatory variables are significant, often with signs that accord with intuition. U.S. investors prefer firms that are larger, included in the MSCI World index, and pay dividends. They are also attracted to firms from Canada and firms with low dividend tax withholding rates. The latter result indicates that an additional reason that a home bias might exist is that U.S. investors shy away from international investments when crossborder dividend tax withholding rates are high. Holdings are higher for firms in industries with a larger share of imports in U.S. supply, which is consistent with the intuition that greater economic proximity increases investment.

A number of the non cross-listed holdings estimates indicate that U.S. investors are sensitive to the amount and quality of information available on foreign-traded firms. The positive

\footnotetext{
${ }^{25}$ To make our results more readily interpretable, we report rescaled functions of the estimates. Specifically, for the coefficients on instruments in the listing decision equation, we calculate the marginal effect of a one-unit change in the instrument on the percentage point probability of cross-listing. Similarly, the coefficients in the holdings equations are scaled to reflect the marginal effect of a change in the instrument on the holdings share of U.S. investors (measured in percentage points). See Appendix B for complete details on transformations and on the estimation technique.
} 
and statistically significant signs on the firm- and country-level accounting variables suggest that U.S. investors value high-quality disclosure when choosing a foreign firm in which to invest. This is consistent with Bradshaw, Bushee, and Miller [2004], who show that U.S. investment is higher in firms with greater conformity to U.S. GAAP.

The only surprising result for non-cross-listed firms is the negative association between holdings and the level of shareholder rights protection provided by a firm's home country. This result holds whether we use the LaPorta, Lopez-de-Silanes, Shleifer, and Vishny [1998] index of anti-director rights (as reported), or country-level estimates of the blockholder premium in share prices from Dyck and Zingales [2004] (not reported). The willingness of American investors to undertake larger positions in firms from countries in which minority shareholders are vulnerable suggests a relative lack of concern about institutional enforcement of their property rights, or that U.S. investors do not feel they will be protected, regardless of shareholder rights scores. ${ }^{26}$

Finally, the selectivity correction variable is negative and significant, indicating that the set of firms that are unlisted have unobservable characteristics that make their stock less likely to be held by U.S. investors. In other words, holding all else constant, the mean holdings of the unlisted sample would be higher if the sample were drawn randomly from a group of firms with the same observable characteristics.

\subsubsection{Determinants of additional holdings in cross-listed firms}

For the determinants of holdings of cross-listed firms, we report our results for the various instruments $\left(\mathbf{Z}_{\mathbf{i}}^{\mathbf{H}}\right)$ in terms of the impact $\left(\beta_{L}-\beta_{U}\right)$ on the increase in U.S. holdings as a result of cross-listing (the right column of Table 4), from our estimated parameters for equations (7) and (8). Only the coefficient on the MSCI member dummy is significant, with the expected negative

\footnotetext{
${ }^{26}$ While the relationship is negative at the firm level, it is essentially zero at the country level. That is, we formed country-level U.S. holdings of non-cross-listed firm by aggregating the firm-level data; across countries, the correlation between that measure and shareholder rights is essentially zero.
} 
sign implying a smaller (by 12 percentage points) cross-listing effect for the relatively large and liquid MSCI member firms.

\subsubsection{The cross-listing decision and U.S. holdings}

In accordance with our intuition about factors that reduce the costs of cross-listing, the estimates for the cross-listing equation (the first column) reveal that firms are more likely to crosslist on a U.S. exchange if they are large, have better home-country accounting standards, or are domiciled in Canada. Firms in industries with greater imported share of U.S. supply are more likely to cross-list. Two of the three variables that uniquely identify the listing equation enter with estimated signs that are in line with our expectations: firms that are closely held and from more liquid markets are less likely to cross-list on a U.S. exchange. Interestingly, firms domiciled in Civil Law countries are less likely to list. While this result runs counter to the intuition that these firms would benefit more, it may be the case the firms from non Civil Law countries find crosslisting less costly. Neither the expected increase in U.S. investment from cross-listing nor the level of U.S. holdings prior to listing influences the cross-listing probability. ${ }^{27}$

\subsection{The average cross-listing effect}

Estimates of the average cross-listing effect are summarized in Table 5. At the end of 1997 U.S. investors held an average of 16.5 percent of the market capitalization of the 282 cross-listed firms (row 1), an average that is slightly less than for the somewhat larger sample in Table 3. Accordingly, for our Heckman-based and p-matching (cross-sectional) estimates of the average cross-listing effect, we use 16.5 percent as our estimate of $\mathrm{E}\left(\mathrm{H}_{\mathrm{i}}^{\mathrm{L}} \mid \mathrm{X}=1\right)$.

The Heckman [1979]-based estimate of $\mathrm{E}\left(\mathrm{H}_{\mathrm{i}}^{\mathrm{L}} \mid \mathrm{X}=0\right)$ is 5.9 percent of market capitalization

\footnotetext{
${ }^{27}$ Specifications exist in which both of these variables are significant, suggesting that firms cross-list to both expand their investor base and service their existing U.S. investor base. However, in many specifications, including the one reported, there are insignificant, owing in part to the relatively small number of firms that have cross-listed.
} 
(row 2). This is larger than average holdings of non-cross-listed firms (2.9 percent of market cap), as cross-listed stocks have attractive features even without the cross-listing. But the Heckman [1979]-corrected estimates still suggest a sizeable, statistically significant cross-listing effect: U.S. holdings in a typical cross-listed stock are 10.6 percentage points of market capitalization (or 13.4 percent in terms of float) higher than they would be without the U.S. listing. ${ }^{28}$

The p-matching and difference-in-differences methodologies produce results that are close to the Heckman [1979]-based estimates. The p-matching produces an estimate of $\mathrm{E}\left(\mathrm{H}_{\mathrm{i}}^{\mathrm{L}} \mid \mathrm{X}=0\right)$ equal to 5.3 percent of market capitalization or 8.1 percent of market float (row 4), implying a statistically significant listing effect equivalent to 11.2 percent of market capitalization (17.7 percent of market float). The bottom panel of Table 5 shows that in March 1994, U.S. investors held 8.6 percent of market capitalization of the 132 firms that were not cross-listed then but that cross-listed by December 1997 (and for which March 1994 U.S. holdings data exist). Adding the 0.6 percentage increase in the holdings of non-cross-listed firms over the period 1994-1997 yields our highest estimate of $\mathrm{E}\left(\mathrm{H}_{\mathrm{i}}^{\mathrm{L}} \mid \mathrm{X}=0\right), 9.2$ percent of market capitalization. Nonetheless, with U.S. investors holding 17.1 percent of these firms by the end of 1997, this still implies an average cross-listing effect of 7.9 percent. ${ }^{29}$ Overall, the three techniques estimate a sizeable average crosslisting effect that ranges from 8 to 11 percent of market capitalization (or 13 to 18 percent of float).

\footnotetext{
${ }^{28}$ The standard error for the listing effect estimate is calculated as the observation-weighted standard deviation of the 279 paired differences.

${ }^{29}$ In our sample, 23 of the 132 firms that cross-listed between the two survey dates also undertook seasoned equity offerings (SEOs). It is plausible that the combination of a SEO and cross-listing has different implications for U.S. holdings than a cross-listing alone, particularly if the issue targets U.S. investors. However, when we compare the change in U.S. holdings for cross-listing stocks with and without these SEOs, we find no statistically significant difference. Accordingly, we do not treat cross-listing firms that raise public equity differently from other cross-listing firms. For further evidence on the capital-raising behavior of cross-listed firms, see Reese and Weisbach [2002] and Henderson, Jegadeesh, and Weisbach [2006].
} 


\subsection{What is behind the cross-listing effect?}

\subsubsection{Is it the firm or the security?}

It is natural to wonder whether the cross-listing effect might reflect information about the firm or might just be due to the fact that the security is available in the United States. We address this question in two ways and find that while there is some advantage to the shares trading directly in the U.S., it does not entirely explain either the cross-listing effect or the observed pattern of holdings in both the U.S.-traded security and the underlying security.

Table 6 shows that for cross-listed firms, U.S. investors hold large proportions of their shares (11.1 percent of market capitalization) in the underlying foreign security purchased in the foreign home market and only a small portion (6.4 percent) in the ADR purchased in the US. This fact has an important implication. ADRs enable U.S. investors to forego concerns about trading in other currencies, dealing directly with foreign regulatory authorities, and potentially high execution costs on foreign stock markets. If investors were responding to the reduction in transactions costs associated with being able to trade these stocks on the NYSE, we would expect most of the cross-listed holdings to be in the form of ADRs. In contrast, most U.S. holdings in cross-listed firms are in the underlying foreign security. This is direct evidence against transaction costs as a primary impediment to foreign investment.

Additional evidence on the motives for holding cross-listed shares is provided by a set of vehicles (Level I and Rule 144a ADRs) that are denominated in dollars and trade in the United States, but trade over-the-counter rather than on an organized exchange. ${ }^{30}$ There are important differences between over-the-counter Level I and Rule 144a ADRs and their exchange-traded Level II and III cousins. Importantly, because they are not listed on a major U.S. exchange, firms

\footnotetext{
${ }^{30}$ In this paper's main analysis we treat Level I and Rule 144a firms as non-cross-listed firms. Note that many Level I ADR programs have been initiated by U.S. investors or depository banks, not by the foreign companies themselves. Rule 144a programs typically arise from private placements available only to institutional investors.
} 
with Level I or Rule 144a ADRs are not required to reconcile financial statements with U.S. GAAP or submit regular disclosures to the SEC and are not subject to most U.S. securities laws. Thus, Level I and Rule 144a ADRs provide U.S. investors the opportunity to acquire foreign stocks that trade in the US but sit outside the protections of U.S. securities regulation. The middle of Table 6 shows that U.S. investors do hold a greater proportion of shares in a Level I and Rule 144a ADR-firm (8.9 percent of market capitalization, 15.1 percent of market float) than in the average foreign firm not traded in the United States, but these holdings are substantially lower than in foreign stocks that trade on organized exchanges (Level II and III ADRs) and are thus required to comply with U.S. securities regulations.

While U.S. holdings of Level I/Rule 144a stocks are smaller than those of stocks listed on a U.S. exchange, they are still greater than U.S. holdings of the typical foreign equity. In Table 7, we distinguish between the portion of the increased holdings of Level I/Rule 144a that is due to other firm characteristics and the portion that might be called a "Level I effect". Applying a pmatching methodology to compare holdings of firms that trade in the U.S. OTC market to firms that have no vehicle for U.S. investment, we find that Level I/Rule 144a stocks would have greater than average U.S. holdings even without the program because of the characteristics companies that trade Level 1 shares $(9.6 \%$ of float, compared with $5.1 \%$ of float for foreign firms without a U.S. trading vehicle). But this leaves a statistically significant Level I effect of 5.2\%. This Level I effect is small relative to the $13-18 \%$ effect for cross-listed stocks, but is not insubstantial. A possible reason for this non-negligible Level I effect is that while Level I ADRs and Rule 144a vehicles confer on limited legal protection to U.S. investors, the protections could be important. Indeed, Iliev, Miller and Roth [2011] show that recent SEC rule changes expose foreign firms with unsponsored programs to liability under U.S. law; these come in addition to the potential right to 
sue unsponsored entities in state courts prior to the SEC changes. In addition, the creation of a Level I ADR could facilitate investment by U.S. residents that may face obstacles or extra costs that deter them from directly investing in foreign securities, although as Table 6 showed most of the holdings are in the underlying security, not in the U.S.-traded ADR.

Overall, the evidence in this subsection suggests that the ability to hold a security that trades in the U.S. matters but is just one factor behind the observed increase in investment in cross-listed stocks.

\subsubsection{Other Factors}

Table 8 reports the results from regressions using the difference-in-differences setup to generate firm-level estimates of the cross-listing effect on the U.S. holdings share. Specifically, we regress the 1994 to 1997 change in holdings of stocks that were not cross-listed in 1994 on a cross-listing dummy, its interactions with instruments measured as of 1994 and 1997, and the change in the value of instruments over the 1994 to 1997 period,

$$
\Delta H_{i}=\alpha_{D}+X_{i} \gamma_{D}+X_{i} \mathbf{Z}_{\mathbf{i}}^{1994} \boldsymbol{\beta}_{\mathbf{D}}+\left(\mathbf{Z}_{\mathbf{i}}^{1997}-\mathbf{Z}_{\mathbf{i}}^{1994}\right) \theta_{D}+\mathbf{Z}_{\mathbf{i}}^{1994} \varphi_{D}+\varepsilon_{i}^{D}
$$

where $X_{i}$ equals one if the firm cross-lists in 1997, and zero otherwise. We include changes and first-period levels of the instruments in the regression as controls for changes in firm characteristics and in U.S. investor preferences, respectively. This is essentially a conditional difference-in-differences approach.

For brevity, we report only the interaction estimates $\left(\boldsymbol{\beta}_{\mathbf{D}}\right)$ in Table 8 that identify the marginal influence of the instruments on the cross-listing effect. Overall, the results are consistent with the notion that improvement in the availability and quality of value-relevant information about a firm is a key aspect of cross-listing in U.S. markets. The negative and statistically significant coefficient on a firm's size relative to its industry average indicates that the change in 
holdings for large liquid firms, which may be more transparent than smaller firms, is lower after cross-listing. Additional evidence for the importance of transparency comes from the smaller estimated cross-listing effect for Canadian firms. Because Canadian firms are not required to reconcile to U.S. GAAP or increase disclosures as much upon cross-listing, cross-listing should have less impact on U.S. investors' willingness to hold Canadian stocks.

While we observe evidence that greater transparency reduces the cross-listing effect, results on accounting quality are mixed. For example, we obtain a negative and statistically significant coefficient estimate for the firm-level accounting quality index. The estimates imply that U.S. investors increase their ownership in a cross-listed firm by 2.5 percentage points for every unit decline in the firm's accounting quality index. The coefficient on the cross-listing dummy interacted with the national accounting quality index, however, is positive and statistically significant. There is an increased cross-listing effect for firms from countries with a higher national accounting quality. Overall, the estimates imply that improved firm-level accounting practices linked to cross-listing spurs U.S. investment in firms with previously weak accounting standards, but strong national accounting quality may actually be complementary to cross-listing.

In the second column of Table 8 , to increase the number of observations we present a more parsimonious specification that does not include the accounting variables or the dividendpaying firm dummy. The coefficient estimates on size and the Canadian firm dummy confirm results indicating that more transparent firms have a smaller change in holdings following crosslisting. One further bit of indirect evidence favoring an information explanation is the reduced listing effect for the more liquid stocks that are included in the MSCI World index. To the extent that illiquidity reflects asymmetric information between company insiders and other potential traders, as in the models of Diamond and Verrecchia [1991] and Easley and O'Hara [2004], the 
enhanced disclosure requirements associated with cross-listing will tend to matter more for less liquid stocks.

With a positive coefficient estimated for the interaction of cross-listing with the shareholder rights index, we do not find that U.S. investors respond to the enhanced protections of U.S. securities laws in the manner that has been suggested by some of the proponents of the investor-protection hypothesis. In particular, all else equal, cross-listing has a smaller impact on U.S. investors' holdings for firms from countries with weaker shareholder protection. Our result here does not imply that U.S. investors fail to value shareholder protection provided by other countries' legal systems, but is consistent with cross-listing complementing such legal rights. In fact, to the extent that cross-listing in the United States makes a firm more transparent, legal protections provided to minority shareholders in the home country may become more effective. (Furthermore, the disclosure requirements accompanying a U.S. listing typically include information about home-country legal risks that may leave some U.S. investors better informed about their rights.) What our results $d o$ suggest is that cross-listing in the United States is not a substitute for adequate protection of minority shareholders under the home-country legal system.

\section{Application to Country-Level Studies}

Using a unique dataset, we have demonstrated that cross-listing is the most important determinant of U.S. international investment and, importantly, that incorporating cross-listing introduces a selection bias that requires estimation with appropriate econometric techniques. Of course, in many research projects such a detailed and complete security-level dataset might not be available. Nevertheless, the insights gleaned are still applicable to more aggregated data sets. Much research on international investment uses country-level data, so as an aid to future research 
we suggest a way for country-level studies to include the effect of cross-listing and address the selection issue in an econometrically robust way.

We start from the view that any country-level study of U.S. international equity investment must have three features: the dependent variable must be float adjusted, the dependent variable should be free of a country-size bias, and the analysis must properly account for cross-listing.

That the dependent variable must be float adjusted is well established in Dahlquist, Pinkowitz, Stulz, and Williamson [2003] and Kho, Stulz, and Warnock [2009]; shares held by insiders are not available to dispersed portfolio shareholders and so should be omitted from portfolio analysis. While there is no exact measure of insider ownership that is available both across a range of countries and through time, a country-level measure built up from the firm-level closely-held field in Worldscope is a reasonable proxy.

Less well understood, but explored in detail in Bekaert, Siegel and Wang [2012], is that the dependent variable should be free of a country-size bias. Common dependent variables that contain a country-size bias that researchers are unable to adequately control for include the dollar amount of holdings or variants thereof (e.g., Desai and Dharmapala [2011]), the share of the country's equities in U.S. portfolios (e.g, Andrade and Chhaochharia [2010], and even a 'difference home bias' measure, that would at first glance appear to account for country size. Bekaert, Siegel and Wang [2012] suggest a measure similar to the following, which they label as a 'foreign bias' vis-à-vis a country $i\left(F B_{i}\right)$ :

$$
\begin{aligned}
& \mathrm{FB}_{\mathrm{i}}=\frac{\mathrm{F}_{\mathrm{i}} / \mathrm{F}_{\text {world }}-\mathrm{USH}_{\mathrm{i}} / \mathrm{USH}_{\text {world }}}{\mathrm{F}_{\mathrm{i}} / \mathrm{F}_{\text {world }}}, \text { if } \mathrm{USH}_{\mathrm{i}} / \mathrm{USH}_{\text {world }}<F_{\mathrm{i}} / \mathrm{F}_{\text {world }} \\
& \mathrm{FB}_{\mathrm{i}}=-\left(\frac{\mathrm{USH}_{\mathrm{i}} / \mathrm{USH}_{\text {world }}-\mathrm{F}_{\mathrm{i}} / \mathrm{F}_{\text {world }}}{1-\mathrm{F}_{\mathrm{i}} / \mathrm{F}_{\text {world }}}\right) \text {,if } \mathrm{USH}_{\mathrm{i}} / \mathrm{USH}_{\text {world }}>F_{\mathrm{i}} / \mathrm{F}_{\text {world }}
\end{aligned}
$$


where $F$ is float and USH is U.S. holdings, both in U.S. dollars. ${ }^{31}$ Note that as defined, a decrease in $F B$ vis-à-vis a particular country $i$ is equivalent to increased U.S. holdings (relative to the country's weight in the world float portfolio).

The $F B$ measure is both suggested by theory (international CAPM) and free of any country-size bias. The reader might readily accept that holdings expressed in dollars (or log dollars) or as a share of the U.S. portfolio has a country size bias, but might expect a difference bias measure (essentially the numerator from above) to be free of such bias. However, as Figure 1 shows, the difference home bias measure has a substantial country size bias; a ratio home bias measure a la Bekaert, Siegel and Wang [2012] does not. ${ }^{32}$

The third requirement, properly incorporating cross-listing into the analysis, calls for appropriate econometric techniques as well as a country-level cross-listed variable. For a countrylevel cross-listing variable, we calculate the fraction of the destination country market capitalization that is cross-listed on a U.S. exchange. ${ }^{33,34}$ For the econometrics, our security-level analysis indicated that cross-listing is endogenous. At the country level a straightforward way to deal with this endogeneity is to instrument for a country's cross-listed fraction. We select a parsimonious list of instruments from our Table 4 and Doidge et al [2009]: trading volume,

\footnotetext{
${ }^{31}$ The underlying U.S. holdings data can be taken from the IMF Coordinated Portfolio Investment Surveys (CPIS). We normally would not advise the use of these data, which are typically of poor quality. But, for U.S. investment abroad, the entries come from high quality U.S. benchmark surveys (except for 2002, when no such survey was conducted and the U.S. CPIS numbers were based on estimates in Thomas, Warnock, and Wongswan [2004]).

${ }^{32}$ Note that at a point in time the top line in equation (10) is essentially equivalent to U.S. holdings as a percent of the destination country's float (times a measure that is constant across countries at a point in time, the share of the U.S. in the world portfolio), another reasonable measure for studies limited to one source country and one time period.

${ }^{33}$ We scale our country-level cross-listing variable using annual country-level market capitalization from the World Bank Development Indicators. Calculating the market capitalization of U.S. listed stocks is not straightforward. Our technique is to aggregate the market capitalization of firms in the CRSP (i.e., U.S.-listed) universe that are incorporated outside the U.S. ( $\operatorname{shcd}=12$ ) or ADRs ( $\operatorname{shrd}=30$ or 31 ) by year and by country, using Compustat calendar price ( $\left.p r c c \_c\right)$ and shares outstanding ( $c s h o$ ) data and the foreign incorporation code (fic). This approach is not foolproof. For example, Accenture PLC switched incorporation from Bermuda to Ireland in 2009, and so is now Irish based on the current CRSP variable shrcd. Thus, for a financial center like Ireland we rely only on information on ADRs to indicate U.S.-listed Irish stocks.

${ }^{34}$ Our cross-listing variable and float adjustment are posted at http://www.nber.org/data-appendix/w17839/.
} 
national accounting quality, a dummy variable for countries with a civil law origin, bilateral trade linkages (exports plus imports between the U.S. and destination country divided by total trade of U.S., often referred to as economic proximity), and log GDP per capita. ${ }^{35}$ As an example, in a pooled 2001-2009 annual dataset these instruments explain a large amount of the variation in the cross-listed fraction (first column of Table 9). Moreover, a comparison of the second and third columns suggests that they do not—once the cross-listed fraction is taken into account—have additional explanatory power for float-adjusted bias. This short list of instruments appears to be suitable to address the selection issue of a country-level cross-listing effect in an econometrically robust way, as the proposed country-level instruments can explain a large portion of the variation in the cross-listed fraction and any subsequent effect on holdings is likely through the effect on cross-listing.

We apply this selectivity adjustment to the analyses in Andrade and Chhaochharia [2010] and Desai and Dharmapala [2011]. Our objective here is not to overturn the results from either paper, but rather to show how the insights from our work can be applied to the burgeoning literature on country-level U.S. international investment.

Like many studies of international investment, Andrade and Chhaochharia [2010] includes a range of control variables but focuses on one variable in particular, in this case the amount of U.S. Foreign Direct Investment (FDI) in each destination country in 1990, a proxy for information endowment. We focus on the main specifications from their Table 3 using a float-adjusted bias measure (somewhat analogous to the non-float-adjusted bias measure used in their Table B2), rather than a country-size-bias plagued portfolio weight measure, and can closely replicate their

\footnotetext{
${ }^{35} \mathrm{We}$ do not claim that our list of country-level instruments is exhaustive, and leave for future work the search for the ultimate instrument set. We note that we also tried a closely held measure (from Worldscope) as an instrument, as suggested by Doidge et al. [2009], but it was not associated with country-level cross-listing and was associated with U.S. holdings, suggesting that it is a poor country-level instrument. Note that Doidge et al. [2009] use a finer measure of insider ownership that is not available across time (or, generally, to other researchers).
} 
results. ${ }^{36}$ As the first column in Table 10 shows, when replicating their results, countries with more U.S. FDI in 1990 had more U.S. international investment (i.e., less bias) in the 2001-2009 period.

But cross-listing is an important omitted variable - one that is potentially correlated with variables of interest. ${ }^{37}$ Specifically, all else equal, countries that receive a lot of US FDI relative to their market float should tend to be the ones with capital markets that are underdeveloped relative to the underlying investment opportunities. Firms in such countries would have relatively strong incentives to cross-list to attract more international ownership, so cross-listing is a potentially important omitted variable correlated with the study's variable of interest.

We illustrate this in the second and third specifications of Table 10. In the second specification, in a simple OLS regression of float-adjusted bias on the same explanatory variables as Andrade and Chhaochharia [2010] - FDI position in 1990, the share of a country's market capitalization in the world market portfolio, and the volatility of stock returns in the destination country-we add the cross-listed fraction. ${ }^{38}$ As expected, the coefficient on the fraction of destination country market capitalization cross-listed in the U.S. is negative and statistically significant; the larger the percent of a country's market capitalization that is cross-listed, the larger is U.S. investment (the smaller is the bias). But the coefficient on FDI 1990 switches sign and is insignificant.

While including the cross-listed fraction solves the omitted variable problem, it does not address the endogeneity that arises from the selection issue. Because holdings and cross-listings are simultaneously determined, all coefficient estimates are inconsistent. In the third specification,

\footnotetext{
${ }^{36}$ Additionally, we update their results using data through 2009 and have a slightly different sample (35 countries versus their 38) because of our instrument choice. Neither of these differences materially impacts the results.

${ }^{37}$ Andrade and Chhaochharia [2010] describe a robustness check that includes fraction of equity cross-listed in 1997, but not a time series that spans the sample used in the analysis.

${ }^{38}$ See Appendix Table A2 in Andrade and Chhaochharia [2010] for details on the construction of their variables.
} 
we estimate the effect of cross-listing using an IV regression and instrument for the cross-list fraction using the instruments proposed earlier. ${ }^{39}$ The coefficient on the cross-list fraction increases and is still negative and statistically significant. The coefficient on FDI 1990 is again insignificant. $^{40}$

We next apply the same type of adjustment to the Desai and Dharmapala [2011] analysis of the impact of changes in dividend tax treatment on U.S. international equity investment. The policy change examined is the Jobs and Growth Tax Relief Reconciliation Act (JGTRRA) of 2003, which lowered the dividend tax rate to $15 \%$ for a particular subset of countries with which the U.S. has a tax treaty. Desai and Dharmapala [2011] find evidence of a substantial portfolio reallocation toward countries for which the tax treaty applied.

While we would argue that cross-listing is an important omitted variable in the Desai and Dharmapala [2011] study, it is less obvious that it should be correlated with their variable of interest. For any cross-listing prior to the treaty date, for there to be a meaningful correlation the treaty countries would have had to been chosen based on cross-listing (or, by extension, U.S. investment since cross-listing is the most important determinant of U.S. investment). More generally, a common trend in the relative bias for treaty countries could induce a positive correlation between the cross-list fraction and the tax policy variable. So while a priori we suspect

\footnotetext{
${ }^{39}$ In unreported results from the first stage regression, the p-value from a test of the overidentifying restrictions is 0.55 , indicating that we cannot reject the null hypothesis that the proposed instruments are suitably exogenous. Instruments must be chosen for a particular application. In Table 8 our goal was to identify a parsimonious set of economically important instruments that is broad enough to be candidates for a range of studies. For the particular application in Table 9, a narrower set of three instruments (trading volume, national accounting quality, and civil law) better meet the criteria for good instruments. For continuity the results in Table 9 use all proposed instruments from Table 8; using 3 instruments (instead of the 5) has no perceptible impact on the results.

${ }^{40}$ If we use a size-biased dependent variable like the raw unadjusted portfolio weights, compared to specification (1) the effect of FDI is reduced but still significant and the effect of Cross-List Fraction - without accounting for the endogeneity - is very strong. If we instrument for the Cross-List Fraction, the magnitude of the effect of cross-listing increases and the effect of FDI is almost halved but remains statistically significant.
} 
that the correlation between the 2003 JGTRRA policy change and cross-listing is muted, we cannot readily dismiss the potential for an omitted variable problem.

We examine this in specifications (4) - (6) of Table 10. Again, for the dependent variable we use a float-adjusted bias measure similar to that in Bekaert, Siegel and Wang [2012], rather than a size-biased measure. The variable of interest in Desai and Dharmapala is an indicator (PostJGTRRA) that equals one for the years after the 2003 enactment of JGTRRA for countries covered by the treaty. Column (4) is analogous to the baseline regression in Desai and Dharmapala (their Table 3, column 2). PostJGTRRA is highly significant; U.S. investment increased (bias decreased) in countries covered by the treaty. In columns (5) and (6) we bring in the cross-list fraction, first as an exogenous independent variable, then as an endogenous one instrumented as in Table 9. In both columns, the cross-list fraction is highly significant and negative, as expected. The coefficient on PostJGTRRA is still negative and significant when cross-listing is includedsuggesting that the variable is not highly correlated with cross-listing — but the magnitude of the effect decreases by more than a third. ${ }^{41}$

As noted above, our objective here is not to overturn or weaken the results of Andrade and Chhaochharia [2010] or Desai and Dharmapala [2011]. Moreover, the effect of including the cross-list fraction depends on the relationship between this potentially important omitted variable and any other proposed determinant of foreign investment. In both cases, it is likely that another specification could be found that re-establishes the strength of their main results. Rather, our objective is merely to show how the insights from our work can be applied to the burgeoning literature on country-level international investment. A variable measuring the fraction of a market

\footnotetext{
${ }^{41}$ One difference between our specification and that in Desai and Dharmapala [2011] is that they include country fixed effects. Including country fixed effects in our specification (5) has no material effect on the results. In our specification (6), including country fixed effects rules out the use of some instruments and, not surprisingly, the instrumented cross-list fraction is insignificant.
} 
cross-listed on U.S. exchanges should be included as an explanatory variable, preferably as an endogenous regressor. Doing so might render coefficients on other variables of interest insignificant or decrease their magnitude, perhaps to be expected when an omitted variable bias is addressed.

We view the applications in the section as illustrative. Future work should aim to refine the modeling of the endogeneity of cross-listing.

\section{Conclusion}

Using comprehensive survey data, we document that the aggregate foreign equity portfolio of all U.S.-resident investors has deviated sharply from market weights. Cross-sectional analysis of U.S. residents' investment choices indicates that U.S. portfolio flows have tended to gravitate toward larger, more liquid, and more transparent firms. However, our selection bias-corrected estimates indicate that cross-listing is by far the most important determinant of U.S. investment in foreign equities. Non-cross-listed foreign firms have roughly 3 percent U.S. ownership. Crosslisted firms, even prior to the cross-listing, have characteristics that are attractive to U.S. investors; all of their attractive (pre-cross-listing) attributes result in an average of 3.5-6 percent more U.S. investment. On top of that we estimate, using various techniques, that a cross-listing in the United States leads to an increase in U.S. holdings of 8 to 11 percent of firm market capitalization, doubling (or more) the amount prior to cross-listing. By examining the holdings in firms that trade over the counter in the U.S. but are not cross-listed on a U.S. exchange, we can rule out that trading costs drive this effect. Rather, it appears that firms that become more informationally transparent following the cross-listing, particularly those firms with poor accounting practices prior to listing in the United States, experience the largest increase in U.S. investment.

Our results present a clear challenge for future research on international investment. Cross- 
listing, which we find to be the most important factor behind U.S. international equity investment, must be considered in any analysis. Moreover, given that cross-listing is a decision often made by otherwise attractive foreign firms, econometric techniques must be used that can appropriately deal with issues of selection bias. To illustrate this point, we show how to apply the lessons of firm-level investment to country-level studies and find that results are sensitive both to accounting for cross-listing as well as for estimating the effect in an econometrically appropriate way. In addition to addressing the important effect of cross-listing, any study at the country level must employ a measure of investment that is both float-adjusted and free from any size bias.

But emphasizing that selection bias requires careful econometric modeling also has implications that reach far outside the literature on international investment. For example, the corporate finance literature on the valuation impact of cross-listing has yet to fully deal with selection bias. ${ }^{42}$ Our hope is that this paper can spark innovations in that literature as well.

\footnotetext{
${ }^{42}$ See the debate that began with Doidge, Karolyi, and Stulz [2004] and has continued through Gozzi, Levine, and Schmukler [2008] and Sarkissian and Schill [2010], among others.
} 


\section{References}

Aggarwal, R., L. Klapper, and P. Wysocki, 2005, Portfolio preferences of foreign institutional investors, Journal of Banking and Finance 29, 2919-2946.

Ahearne, A., W. Griever, and F. Warnock, 2004, Information costs and home bias: an analysis of U.S. holdings of foreign equities, Journal of International Economics 62, 313-336.

Amiram, D., and Mary Margaret Frank, 2010, The Effects of the Taxation of Dividends on the Allocation of Foreign Portfolio Investment Around the World, (available at http://ssrn.com/abstract=1539422).

Andrade, S. C. and V. Chhaochharia, 2010, Information Mobility and Foreign Portfolio Investment, Review of Financial Studies 23, 2429-2463.

Bekaert, G., S. Siegel, and X. Wang, 2012, Home bias revisited, unpublished working paper.

Bernstein, S., J. Lerner, and A. Schoar, 2009, The Investment Strategies of Sovereign Wealth Funds, NBER WP 14861.

Bradshaw, M. T., B. J. Bushee, and G. S. Miller, 2004, Accounting choice, home bias, and U.S. investment in non-U.S. firms, Journal of Accounting Research 42(5), 795-841.

Bushman, R., J. Piotroski, and A. Smith, 2004, What determines corporate transparency? Journal of Accounting Research 42(2), 207-251.

Chan, K., V. Covrig and L. Ng, 2005, What determines the domestic bias and foreign bias? Evidence from mutual fund equity allocations worldwide, Journal of Finance 60, 1495-1534.

Dahlquist, M., L. Pinkowitz, R. Stulz, and R. Williamson, 2003, Corporate governance and the home bias, Journal of Financial and Quantitative Analysis 38, 87-110.

Dehejia, R. and S. Wahba, 2002, Propensity score matching methods for non-experimental causal studies, Review of Economics and Statistics 84, 151-161.

Desai, M., and D. Dharmapala, 2011, Dividend taxes and international portfolio choice, Review of Economics and Statistics 93(1): 266-284.

Diamond, D. W., and R. E. Verrecchia, 1991, Disclosure, Liquidity, and the Cost of Capital, Journal of Finance 46(4), 1325-59.

Didier, T., R. Rigobon, and S. Schmukler, 2010, Unexploited Gains from International Diversification: Patterns of Portfolio Holdings around the World, mimeo.

Doidge, C., G.A. Karolyi, and R. Stulz, 2004, Why are foreign firms listed in the U.S. worth more? Journal of Financial Economics 71, 205-238.

Doidge, C., G.A. Karolyi, K. Lins, D. Miller, and R. Stulz, 2009. Private Benefits of Control, Ownership, and the cross-listing decision, Journal of Finance 64(1), 425-466. 
Drake, C., 1993, Effects of misspecification of the propensity score on estimators of treatment effects, Biometrics 49, 1231-1236.

Durnev, A. and H. Kim, 2005, To Steal or Not to Steal: Firm Attributes, Legal Environment, and Valuation, Journal of Finance 60(3): 1461-1493.

Dyck, A.and L. Zingales, 2004, Private Benefits of Control: An International Comparison, Journal of Finance 59(2), 537-600.

Easley, D., and M. O'Hara, 2004, Information and the Cost of Capital, Journal of Finance 59(4), 1553 1583.

Easterbrook, F., 1984, Two Agency Cost Explanations of Dividends, American Economic Review 74(4), 650-659.

Edison, H. J., and F. Warnock, 2004, U.S. Investors' Emerging Market Equity Portfolios: A Security-Level Analysis, Review of Economics and Statistics 84(3), 691-704.

Faccio, M., L. Lang, and L. Young, 2001, Dividends and Expropriation, American Economic Review 91(1), 54-78.

Fanto, J., and R. Karmel, 1997, A report on the attitudes of foreign companies regarding a U.S. listing, Stanford Journal of Law, Business and Finance 24, 763-812.

Ferreira, M., and P. Matos, 2008, The colors of investors' money: The role of institutional investors around the world, Journal of Financial Economics 88, 499-533.

Fidora, M., M. Fratzscher, and C. Thimann, 2007, Home Bias in Global Bond and Equity Markets: The Role of Real Exchange Rate Volatility, Journal of International Money and Finance 26, 631-655.

Foerster, S. R., and G. A. Karolyi, 1999, The effects of market segmentation and investor recognition on asset prices: Evidence from foreign stocks listing in the United States, Journal of Finance 54, 981-1013.

Glassman, D. A. and L. A. Riddick, 2001, What causes home asset bias and how should it be measured? Journal of Empirical Finance 8, 35-54.

Glazerman, S., D. Levy, and D. Myers, 2003, Nonexperimental versus experimental estimates of earnings impacts, The Annals of the American Academy of Political and Social Science 589, 63-93.

Gozzi, J., R. Levine, and S. Schmukler, 2008, Internationalization and the evolution of corporate valuation, Journal of Financial Economics 88(3), 607-632.

Griever, W., G. Lee, and F. E. Warnock, 2001, The U.S. system for measuring cross-border investment in securities: a primer with a discussion of recent developments, Federal Reserve Bulletin, 87(10): 633-650.

Heckman, J. J., 1979, Sample selection bias as a specification error, Econometrica 47, 153-161.

Heckman, J., H. Ichimura, J. Smith, and P. Todd, 1998, Characterizing selection bias using experimental data, Econometrica, 66, 1017-1098.

Heckman, J., R. LaLonde, and J. Smith, 1999, The economics and econometrics of active labor market 
programs, in O. Ashefelter and D. Card, eds, Handbook of Labor Economics, Amsterdam: Elsevier.

Heckman, J. and R. Robb Jr., 1985, Alternative methods for evaluating the impact of interventions, in Longitudinal Analysis of Labor Markets Data, ed. By J. Heckman and B. Singer. New York: Cambridge University Press, pp. 156-245.

Henderson, B., N. Jegadeesh, and M. Weisbach, 2006, World markets for raising new capital, Journal of Financial Economics 82, 63-101.

Imbens, G. W. 2004, Nonparametric estimation of average treatment effects under exogeneity: a review, Review of Economics and Statistics 86, 1, 4-29.

Iliev, P., D. Miller. and L. Roth, 2011, Uninvited U.S. Investors? Economic Consequences of Involuntary Cross-listings. SSRN working paper.

International Finance Corportation, 1998, Emerging Stock Markets Factbook.

Jensen, M., 1986, Agency Cost of Free Cash Flow, Corporate Finance, and Takeovers, American Economic Review (Papers and Proceedings) 76(2), 323-329.

Johnson, S,, R, La Porta, F, Lopez-de-Silanes, and A, Shleifer, 2000. Tunneling. American Economic Review (Papers and Proceedings) 90, 22-27,

Kalcheva, I,, and K, Lins, 2007. International evidence on cash holdings and expected managerial agency problems, Review of Financial Studies 20: 1087-1112.

Karolyi, A. and R. Stulz, 2003, Are assets priced locally or globally?, in G. Constantinides, M. Harris and R. Stulz, eds.: The Handbook of the Economics of Finance, North-Holland Publishers, New York, NY.

Kho, B., R. Stulz, and F. Warnock, 2009, Financial globalization, governance, and the evolution of the home bias, Journal of Accounting Review 47: 597-635.

Lalonde, R., 1986, Evaluating the econometric evaluations of job training programs with experimental data, American Economic Review 76, 604-620.

Lane, P., and G.M. Milesi-Ferretti, 2008, International Investment Patterns, Review of Economics and Statistics 90(3), 538-549.

Lang, M., K. Lins, and D. Miller, 2003, ADRs, analysts, and accuracy: Does cross listing in the U.S. improve a firm's information environment and increase market value? Journal of Accounting Research 41(2), 317-345.

La Porta, R. F. Lopez-de-Silanes, A. Shleifer, and R. Vishny, 1998, Law and finance, Journal of Political Economy 106, 1113-1155.

La Porta, R. F. Lopez-de-Silanes, A. Shleifer, and R. Vishny, 1999, Corporate ownership around the world, Journal of Finance 54, 471-515.

La Porta, R., F. Lopez-de-Silanes, A. Shleifer, and R. Vishny, 2002, Investor Protection and Corporate Valuation, Journal of Finance, Vol. 57(3), 1147-1170. 
Larcker, D., T. Rusticus, 2010, On the Use of Instrumental Variables in Accounting Research, Journal of Accounting and Economics 49(3): 186-205.

Lee, L.F., 1978, Unionism and wage rates: A simultaneous equations model with qualitative and limited dependent variables, International Economic Review, 19, 415-433.

Leuz, C., Lins, K., and F. Warnock, 2009, Do foreigners invest less in poorly governed firms? Review of Financial Studies, 22, 3245-3285.

Leuz, C., and R. Verrechia, 2004, The Economic Consequences of Increased Disclosure, Journal of Accounting Research 38: 91-124.

Lewis, K. K., 1999, Trying to Explain Home Bias in Equities and Consumption, Journal of Economic Literature 37, 571-608.

Maddala, G., 1983, Limited-Dependent and Qualitative Variables in Econometrics, Cambridge Press.

Merton, R. C., 1987, A simple model of capital market equilibrium with incomplete information, Journal of Finance 42, 483-510.

Miller, D., 1999, The market reaction to international cross-listings: evidence from depositary receipts, Journal of Financial Economics 51, 103-123.

Morgan, D. P., 2002, Rating banks: Risk and uncertainty in an opaque industry, American Economic Review 92, 874-888.

Pinkowitz, L., R. Stulz, and R. Williamson, 2006, Does the Contribution of Corporate Cash Holdings and Dividends to Firm Value Depend on Governance? A Cross-Country Analysis, Journal of Finance 27252753.

Reese, W., and M. Weisbach, 2002, Protection of minority shareholders interests, cross-listings in the United States, and subsequent equity offerings, Journal of Financial Economics, 66(1): 65-104.

Rosenbaum, P. R. and D. B. Rubin. 1983, The central role of the propensity score in observational studies for causal effects, Biometrika 70, 41-55.

Sarkissian, S., and M. Schill. 2004. The Overseas Listing Decision: New Evidence of Proximity Preference. Review of Financial Studies 17, 769-809.

Sarkissian, S, and M, Schill, 2010. Why are U.S. Firms Listed in Foreign Markets Worth More?, working paper presented at 2010 Western Finance Association meetings.

Stuart, E., 2004, Matching methods for causal inference: Designing observational studies, Harvard University Department of Statistics mimeo.

Thomas, C. P., F. E. Warnock, and J. Wongswan, 2004, The Performance of International Portfolios, International Finance Discussion Paper 2004-817 (Federal Reserve Board).

Yu, Gwen, 2010, Accounting Standards and International Portfolio Holdings: Analysis of Cross-border Holdings Following Mandatory Adoption of IFRS, Ph.D. dissertation, The University of Michigan. 
Zhao, Z., 2004, Using matching to estimate treatment effects: data requirements, matching metrics, and Monte Carlo evidence, Review of Economics and Statistics 86, 1, 91-107. 
Table 1: Sample Count by Country, December 31, 1997

The table shows the number of firms by country for the 12,221 non-U.S. stocks in our end-1997 sample.

\begin{tabular}{|c|c|c|c|}
\hline Country & Number of Firms & Country & Number of Firms \\
\hline Argentina & 41 & Korea & 313 \\
\hline Australia & 284 & Luxembourg & 22 \\
\hline Austria & 106 & Malaysia & 442 \\
\hline Belgium & 134 & Mexico & 84 \\
\hline Brazil & 149 & Netherlands & 181 \\
\hline Canada & 503 & New Zealand & 49 \\
\hline Chile & 92 & Norway & 184 \\
\hline China & 111 & Pakistan & 78 \\
\hline Colombia & 28 & Peru & 28 \\
\hline Czech Republic & 60 & Philippines & 111 \\
\hline Denmark & 207 & Poland & 45 \\
\hline Finland & 113 & Portugal & 97 \\
\hline France & 772 & Russia & 20 \\
\hline Germany & 655 & Singapore & 220 \\
\hline Greece & 139 & South Africa & 206 \\
\hline Hong Kong & 373 & Spain & 151 \\
\hline Hungary & 22 & Sweden & 242 \\
\hline India & 248 & Switzerland & 201 \\
\hline Indonesia & 149 & Taiwan & 234 \\
\hline Ireland & 67 & Thailand & 277 \\
\hline Israel & 55 & Turkey & 79 \\
\hline Italy & 204 & United Kingdom & 2,029 \\
\hline \multirow[t]{2}{*}{ Japan } & 2,402 & Venezuela & 14 \\
\hline & & Total & 12,221 \\
\hline
\end{tabular}




\section{Table 2: Distribution of Firm-Level U.S. Holdings}

The table reports firm-level U.S. holdings scaled by market capitalization and float as of December 31, 1997 for our sample of firms. Data on the value of U.S. holdings are from the U.S. Treasury/Federal Reserve Board survey of U.S. holdings of foreign securities. Market capitalization figures are from Datastream, MSCI, and Worldscope. We calculate market float by scaling market capitalization down by the figure given in Worldscope's "closely held share" field.

\section{U.S. holdings / \\ U.S. holdings /

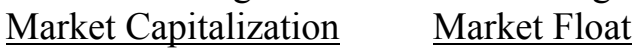

Mean

Percentiles:

$0 \%$

$25 \%$

$50 \%$

$75 \%$

$90 \%$

$95 \%$

Number of firms
$3.5 \%$

$6.3 \%$

$0.0 \% \quad 0.0 \%$

$0.0 \% \quad 0.0 \%$

$0.4 \%$

$1.2 \%$

$3.9 \%$

$7.8 \%$

$10.7 \%$

$19.1 \%$

$16.7 \%$

$29.5 \%$ 


\section{Table 3: Distribution of Firm-Level U.S. Holdings Split by Cross-Listing Status}

The table reports firm-level U.S. holdings scaled by market capitalization and float as of December 31, 1997 for our samples of cross-listed and non cross-listed firms. Data on the value of U.S. holdings are from the U.S. Treasury/Federal Reserve Board survey of U.S. holdings of foreign securities. Market capitalization figures are from Datastream, MSCI, and Worldscope. We calculate market float by scaling market capitalization down by the figure given in Worldscope's "closely held share" field. We classify a non-U.S. firm as cross-listed if its shares are listed on the NYSE, AMEX, or NASDAQ.

\begin{tabular}{|c|c|c|c|c|}
\hline \multirow[b]{2}{*}{ Firms that are: } & \multicolumn{2}{|c|}{$\begin{array}{c}\text { U.S. holdings / } \\
\text { Market Capitalization }\end{array}$} & \multicolumn{2}{|c|}{$\begin{array}{l}\text { U.S. holdings / } \\
\text { Market Float }\end{array}$} \\
\hline & $\begin{array}{c}\text { NOT } \\
\text { CROSS- } \\
\text { LISTED } \\
\end{array}$ & $\begin{array}{l}\text { CROSS- } \\
\text { LISTED }\end{array}$ & $\begin{array}{c}\text { NOT } \\
\text { CROSS- } \\
\text { LISTED }\end{array}$ & $\begin{array}{l}\text { CROSS- } \\
\text { LISTED }\end{array}$ \\
\hline Mean & $2.9 \%$ & $17.5 \%$ & $5.6 \%$ & $26.3 \%$ \\
\hline \multicolumn{5}{|l|}{ Percentiles: } \\
\hline $0 \%$ & $0.0 \%$ & $0.0 \%$ & $0.0 \%$ & $0.2 \%$ \\
\hline $25 \%$ & $0.0 \%$ & $7.2 \%$ & $0.0 \%$ & $11.4 \%$ \\
\hline $50 \%$ & $0.3 \%$ & $13.6 \%$ & $1.0 \%$ & $20.2 \%$ \\
\hline $75 \%$ & $3.3 \%$ & $24.2 \%$ & $6.8 \%$ & $36.7 \%$ \\
\hline $90 \%$ & $9.1 \%$ & $36.4 \%$ & $17.2 \%$ & $51.6 \%$ \\
\hline $95 \%$ & $14.2 \%$ & $43.6 \%$ & $25.7 \%$ & $68.8 \%$ \\
\hline Memo: Value-Weighted Mean & $6.6 \%$ & $15.4 \%$ & $10.2 \%$ & $19.8 \%$ \\
\hline Number of firms & 11,723 & 498 & 8,235 & 293 \\
\hline
\end{tabular}




\section{Table 4: Jointly Estimated Determinants of U.S. Investment and Firms' Cross-listing Decision}

The table reports estimates of a simultaneous system that includes a probit specification of a firm's decision to cross-list and two equations that determine the holdings share of U.S. investors (scaled by market float) - one reflecting holdings conditional on not cross-listing on a U.S. exchange as of December 31, 1997, and one reflecting additional holdings in cross-listed firms. The reported figures are scaled to reflect the median (over the firms in the sample) marginal impact of a unit change in the variable in question, on either the probability of cross-listing (in percent) or on U.S. holding (in percent). E[Gain in U.S. Holdings Share] from Cross-Listing is the endogenously estimated forecast of the change in holdings that would resulting from cross-listing for a given firm and E[U.S. Holdings Share] without Cross-Listing is an analogously defined estimate of what U.S. holdings would be if a firm did not cross-list. The other variables are defined in Appendix A. P-values corresponding to a null hypothesis of a zero median impact appear in parentheses below each reported coefficient estimate. 
Table 4 (cont.): Jointly Estimated Determinants of U.S. Investment and Firms' Cross-listing Decision

\begin{tabular}{|c|c|c|c|}
\hline \multirow[t]{2}{*}{ Percentage-point impact of: } & \multirow{2}{*}{$\begin{array}{l}\text { Cross-Listing } \\
\text { Probability }\end{array}$} & \multicolumn{2}{|c|}{ U.S. Holdings / Market Float: } \\
\hline & & If Not Cross-Listed & If Cross-Listed \\
\hline $\begin{array}{l}\text { E[Gain in U.S. Holdings (\%) Share }] \\
\text { from Cross-Listing }\end{array}$ & $\begin{array}{l}-0.001 \\
(0.494)\end{array}$ & & \\
\hline $\begin{array}{l}\text { E[U.S. Holdings (\%) Share] } \\
\text { without Cross-Listing }\end{array}$ & $\begin{array}{c}0.162 \\
(0.129)\end{array}$ & & \\
\hline Selectivity correction & & $\begin{array}{l}-0.085 \\
(0.000)\end{array}$ & $\begin{array}{l}-0.231 \\
(0.356)\end{array}$ \\
\hline $\begin{array}{l}\text { Proportion of Share Held } \\
\text { by Insiders }(\%)\end{array}$ & $\begin{array}{l}-0.638 \\
(0.058)\end{array}$ & & \\
\hline Trading volume & $\begin{array}{l}-0.804 \\
(0.000)\end{array}$ & & \\
\hline $\begin{array}{l}\text { Ln(Assets) minus } \\
\quad \text { Industry Average of Ln(Assets) }\end{array}$ & $\begin{array}{c}0.457 \\
(0.000)\end{array}$ & $\begin{array}{c}0.986 \\
(0.000)\end{array}$ & $\begin{array}{l}-0.666 \\
(0.746)\end{array}$ \\
\hline Average Industry Market Cap & $\begin{array}{c}1.014 \\
(0.000)\end{array}$ & $\begin{array}{c}1.959 \\
(0.000)\end{array}$ & $\begin{array}{l}-0.717 \\
(0.840)\end{array}$ \\
\hline National accounting quality & $\begin{array}{c}0.072 \\
(0.001)\end{array}$ & $\begin{array}{c}0.065 \\
(0.003)\end{array}$ & $\begin{array}{l}-0.230 \\
(0.445)\end{array}$ \\
\hline Firm-level accounting quality & & $\begin{array}{l}1.078 \\
(0.000)\end{array}$ & $\begin{array}{l}-1.305 \\
(0.602)\end{array}$ \\
\hline Shareholders' anti-director rights & & $\begin{array}{l}-0.339 \\
(0.001)\end{array}$ & $\begin{array}{c}0.022 \\
(0.985)\end{array}$ \\
\hline Dividend withholding tax rate $(\%)$ & & $\begin{array}{l}-0.084 \\
(0.000)\end{array}$ & $\begin{array}{l}-0.070 \\
(0.707)\end{array}$ \\
\hline $\begin{array}{l}\text { Industry-level imported share of } \\
\text { U.S. supply (\%) }\end{array}$ & $\begin{array}{c}2.390 \\
(0.003)\end{array}$ & $\begin{array}{c}0.023 \\
(0.009)\end{array}$ & $\begin{array}{l}-0.103 \\
(0.311)\end{array}$ \\
\hline $\begin{array}{l}\text { Dummy variables: } \\
\text { MSCI member }\end{array}$ & & $\begin{array}{c}7.540 \\
(0.000)\end{array}$ & $\begin{array}{r}-12.090 \\
(0.000)\end{array}$ \\
\hline Dividend-paying firm & & $\begin{array}{c}1.409 \\
(0.000)\end{array}$ & $\begin{array}{l}-1.425 \\
(0.678)\end{array}$ \\
\hline Canadian firm & $\begin{array}{c}2.584 \\
(0.000)\end{array}$ & $\begin{array}{l}5.915 \\
(0.000)\end{array}$ & $\begin{array}{l}-4.816 \\
(0.612)\end{array}$ \\
\hline Civil law & $\begin{array}{c}-0.822 \\
(0.004)\end{array}$ & & \\
\hline Number of observations & 8,086 & 7,804 & 282 \\
\hline
\end{tabular}




\section{Table 5: Average Cross-Listing Effect for Cross-Listed Stocks}

The table reports estimates of the average cross-listing effect using three alternative treatment estimators. The "Heckman-based" estimates (rows 2 and 3 of Panel A) are based on fitted holdings from the non crosslisted holdings equation (4) using data on the cross-listed firms. Parameter estimates for these equations appear in the middle column of Table 4. The "p-matching" estimates (rows 4 and 5) are U.S. holdings of a sample of non cross-listed firms that have been paired with the cross-listed sample on the basis of fitted probabilities from a reduced-form probit model of the cross-listing decision. Panel B presents "differencein-differences" estimates using data on U.S. holdings for March 31, 1994 and December 31, 1997. The sample in Panel B is restricted to stocks that were not cross-listed in U.S. markets in the earlier period, with the columns distinguishing between stocks that cross-listed before the second period and those that did not. Standard errors are shown in parentheses.

$\begin{array}{lcc}\text { Panel A: Heckman-based and P-Matching Methods } & \text { U.S. investors' aggregate holdings as percentage of: } \\ \begin{array}{l}\text { 1. Mean holdings of cross-listed stocks, } \\ E\left(H_{i}^{L} \mid X=1\right)\end{array} & \frac{\text { Market Float }}{25.9} \\ & & 16.5 \\ \text { 2. Heckman-based estimate of } \mathrm{E}\left(\mathrm{H}_{\mathrm{i}}^{\mathrm{L}} \mid \mathrm{X}=0\right) & 5.9 & \mathbf{1 3 . 4} \\ \text { 3. Heckman-based estimate of cross-listing effect, } & \mathbf{1 0 . 6} & \mathbf{( 1 . 3 )} \\ E\left(H_{i}^{L} \mid X=1\right)-E\left(H_{i}^{L} \mid X=0\right) & \mathbf{( 0 . 8 )} & \\ & & \\ \text { 4. } \mathrm{P}-\text {-matching estimate of } \mathrm{E}\left(\mathrm{H}_{\mathrm{i}}^{\mathrm{L}} \mid \mathrm{X}=0\right) & 5.3 & \mathbf{1 7 . 7} \\ \text { 5. P-Matching estimate of cross-listing effect, } & \mathbf{1 1 . 2} & \mathbf{( 1 . 3 )} \\ E\left(H_{i}^{L} \mid X=1\right)-E\left(H_{i}^{L} \mid X=0\right) & \mathbf{( 0 . 8 )}\end{array}$

\begin{tabular}{lcc}
$\begin{array}{l}\text { Panel B: Difference-in-Differences } \\
\text { for U.S. holdings / market cap }\end{array}$ & $\begin{array}{c}\text { Stocks Cross-listed on U.S. } \\
\text { exchange by December 1997 }\end{array}$ & $\begin{array}{c}\text { Stocks not Cross-listed on U.S. } \\
\text { exchange by December 1997 }\end{array}$ \\
\cline { 2 - 3 } $\begin{array}{l}\text { 7. Holdings: March 31, 1994 } \\
\text { 8. Change in holdings }(1994-1997)\end{array}$ & 8.6 & 2.3 \\
9. Difference-in-differences & 17.1 & 2.9 \\
$\begin{array}{l}\text { estimate of cross-listing effect } \\
E\left(H_{i}^{L} \mid X=1\right)-E\left(H_{i}^{L} \mid X=0\right)\end{array}$ & 8.5 & $\mathbf{7 . 9}$ \\
& & $\mathbf{( 0 . 5 )}$ \\
10. Number of Observations & 132 & \\
\hline
\end{tabular}




\section{Table 6: Summary Statistics for Holdings in ADR Form and of Level I ADRs}

The table reports additional information. For cross-listed firms, it reports the amount of U.S. holdings in the actual ADR (as opposed to the underlying foreign equity). For Level I ADRS, which trade only on overthe-counter markets and are not considered to be cross-listed on a U.S. exchange, it reports the amounts held by U.S. investors, as well as the portions held in ADR form and in the underlying foreign equity. For comparison, the table includes data on non-cross-listed firms as well. For further details, see notes to Tables 2 and 3.

\begin{tabular}{ccc}
\hline & $\begin{array}{c}\text { Firm Market } \\
\text { Capitalization } \\
\text { Available } \\
\text { (46 countries) }\end{array}$ & $\begin{array}{c}\text { Firm Market } \\
\text { Float } \\
\text { Available } \\
\text { (46 countries) }\end{array}$ \\
\hline Firms Cross-Listed on a U.S. Exchange & 498 & 293 \\
Average share held by U.S. investors & $17.5 \%$ & $26.3 \%$ \\
Average share held in DR form & $6.4 \%$ & $12.4 \%$ \\
Average share held in underlying equity & $11.1 \%$ & $13.9 \%$ \\
Firms with Level 1 or Rule 144a ADRs & 640 & 466 \\
Average share held by U.S. investors & $8.9 \%$ & $15.1 \%$ \\
Average share held in DR form & $1.8 \%$ & $2.9 \%$ \\
Average share held in underlying equity & $7.1 \%$ & $12.2 \%$ \\
& & \\
Firms with no vehicle for U.S. trading & 11,066 & 7,767 \\
Average share held by U.S. investors & $2.6 \%$ & $5.1 \%$ \\
& & \\
\hline
\end{tabular}


Table 7: Estimated Average Impact of Level 1 or Rule 144a ADRs on U.S. Investment

The table reports estimates of the average effect of Level 1 or Rule 144a ADRs on the share of market float held by U.S. investors, using "p-matching" to correct for selection bias. The middle row shows U.S. holdings of a sample of firms (drawn from those without a vehicle for U.S. trading) that have been paired with the Level 1 / Rule 144a sample on the basis of the fitted probability (of a Level 1 or Rule 144a ADR program) from a first-stage probit model that uses the instruments listed in Table 4. The standard error is shown in parentheses.

\begin{tabular}{|c|c|}
\hline \multicolumn{2}{|c|}{ U.S. investors' aggregate holdings as percentage of market float } \\
\hline $\begin{array}{l}\text { Mean holdings in Level } 1 \text { and Rule 144a ADR firms } \\
\text { (443 firms) }\end{array}$ & 14.8 \\
\hline $\begin{array}{l}\text { P-matching estimate of what holdings would have } \\
\text { been without a Level } 1 \text { or Rule } 144 \text { a ADR program }\end{array}$ & 9.6 \\
\hline P-Matching estimate of Level 1 / Rule 144a effect & $\begin{array}{c}5.2 \\
(0.9)\end{array}$ \\
\hline
\end{tabular}




\section{Table 8: Determinants of the Cross-Listing Effect on the U.S. Holdings Share}

The table reports coefficient estimates from a regression of the change in U.S. holdings (as a percentage of market capitalization) between March 31, 1994 and December 31, 1997 on a cross-listing dummy interacted with 1994 values of the instruments listed in the table. The sample is restricted to stocks that were not cross-listed in U.S. markets in the earlier period. A dummy variable for cross-listing between 1994 and 1997, first-period values of the instruments, and changes in the instruments (between the first and second period) are included as control variables in both equations. P-values (for a null hypothesis of a zero coefficient) are shown in parentheses.

\begin{tabular}{lcc}
\hline \multicolumn{1}{c}{ cross-listing dummy interacted with: } & $(1)$ & $(2)$ \\
\hline Ln(Assets) minus & -1.194 & -1.024 \\
Industry Average of Ln(Assets) & $(0.001)$ & $(0.000)$ \\
Average Industry Market Cap & -0.089 & -1.146 \\
& $(0.933)$ & \\
Firm-level accounting quality index & -2.454 & \\
& $(0.003)$ & \\
Dividend-paying firm dummy & 2.067 & -3.008 \\
& $(0.186)$ & $(0.030)$ \\
MSCI member dummy & -1.221 & \\
& $(0.391)$ & 1.509 \\
National accounting quality index & 0.331 & $(0.003)$ \\
Shareholder rights index & $(0.000)$ & 0.071 \\
Industry-level imported share of U.S. supply (\%) & 0.508 & $(0.144)$ \\
Canadian firm dummy & $(0.388)$ & -8.287 \\
& 0.065 & $(0.000)$ \\
\hline Number Not Cross-Listed & $(0.185)$ & 7,722 \\
Number Cross-Listed & -5.223 & 103 \\
Adjusted R-squared & $(0.002)$ & 0.045 \\
\hline
\end{tabular}




\section{Table 9: Country-Level Cross-Listing Determinants}

The table reports results from panel regressions using annual data from 2001 to 2009 for thirty-five countries. Dependent variables are cross-list fraction (the fraction of foreign market capitalization crosslisted on a U.S. exchange) and a float-adjusted bias measure (bias float, adapted from Bekaert, Siegel and Wang [2012], and defined in Eq. (11)). A decrease in bias float is equivalent to an increase in a country's weight in U.S. portfolios relative to its weight in the world float portfolio. Year time dummies are included in every specification. Standard errors are clustered by destination countries and are robust to heteroskedasticity. P-values are in parentheses.

\begin{tabular}{|c|c|c|c|}
\hline $\begin{array}{l}\text { Dependent Variable: } \\
\text { Cross-List Fraction }\end{array}$ & $\begin{array}{c}\text { Cross-List } \\
\text { Fraction }\end{array}$ & \multicolumn{2}{|c|}{ Bias Float } \\
\hline & & $\begin{array}{l}-0.481 \\
(0.000)\end{array}$ & $\begin{array}{l}-0.472 \\
(0.000)\end{array}$ \\
\hline \multirow{2}{*}{ Trading volume } & 0.023 & & 0.026 \\
\hline & $(0.307)$ & & $(0.158)$ \\
\hline \multirow[t]{2}{*}{ National accounting quality } & 0.007 & & 0.001 \\
\hline & $(0.058)$ & & $(0.802)$ \\
\hline \multirow[t]{2}{*}{ Civil law } & 0.159 & & 0.025 \\
\hline & $(0.015)$ & & $(0.740)$ \\
\hline \multirow[t]{2}{*}{ Economic proximity } & 2.892 & & -0.099 \\
\hline & $(0.000)$ & & $(0.921)$ \\
\hline \multirow{2}{*}{ Log GDP per Capita } & 0.016 & & -0.018 \\
\hline & $(0.490)$ & & $(0.570)$ \\
\hline $\mathrm{N}$ & 315 & 315 & 315 \\
\hline $\mathrm{R}^{2}$ & 0.42 & 0.31 & 0.33 \\
\hline
\end{tabular}




\section{Table 10: Applications of Cross-List Fraction to Country-Level Studies}

The table reports results from panel regressions of the bias float measure of U.S. international equity investment. Bias float, adapted from Bekaert, Siegel and Wang [2012], is defined in Eq. (10). Thirty-five countries from 2001 to 2009 are included in specifications (1)-(3); thirty-seven countries for 1994, 1997, 2001, 2003, 2004, and 2005 are included in specifications (4)-(6). Cross-list fraction is the fraction of the foreign market capitalization that is cross-listed on a U.S. exchange. TreatyPostJGTRRA is an interaction between and indicator variable (Treaty) for countries listed in Desai and Dharmapala [2011] and an indicator (PostJGTRRA) for the years after the enactment of JGTRRA in 2003. The samples in specifications (4)-(6) ends in 2005 because, as noted by Desai and Dharmapala [2011], the treaty countries changed in 2006. Year time dummies are included in every specification. Standard errors are clustered by destination countries and are robust to heteroskedasticity. P-values are in parentheses.

\begin{tabular}{|c|c|c|c|c|c|c|}
\hline & $\begin{array}{c}\text { OLS } \\
(1)\end{array}$ & $\begin{array}{c}\text { OLS } \\
(2)\end{array}$ & $\begin{array}{l}\text { IV } \\
(3)\end{array}$ & $\begin{array}{l}\text { OLS } \\
(4)\end{array}$ & $\begin{array}{c}\text { OLS } \\
(5)\end{array}$ & $\begin{array}{l}\text { IV } \\
(6)\end{array}$ \\
\hline Cross-List Fraction & & $\begin{array}{c}-0.555 \\
(0.000)\end{array}$ & $\begin{array}{c}-0.608 \\
(0.012)\end{array}$ & & $\begin{array}{l}-0.286 \\
(0.000)\end{array}$ & $\begin{array}{c}-0.304 \\
(0.000)\end{array}$ \\
\hline FDI 1990 & $\begin{array}{c}-0.014 \\
(0.067)\end{array}$ & $\begin{array}{c}0.004 \\
(0.544)\end{array}$ & $\begin{array}{c}0.006 \\
(0.489)\end{array}$ & & & \\
\hline World Market Float & $\begin{array}{c}0.028 \\
(0.072)\end{array}$ & $\begin{array}{c}0.013 \\
(0.278)\end{array}$ & $\begin{array}{c}0.011 \\
(0.376)\end{array}$ & $\begin{array}{c}0.045 \\
(0.817)\end{array}$ & $\begin{array}{c}0.255 \\
(0.011)\end{array}$ & $\begin{array}{c}0.270 \\
(0.0055)\end{array}$ \\
\hline Stock Return Volatility & $\begin{array}{c}0.194 \\
(0.246)\end{array}$ & $\begin{array}{c}0.033 \\
(0.849)\end{array}$ & $\begin{array}{c}0.017 \\
(0.924)\end{array}$ & & & \\
\hline TreatyPostJGTRRA & & & & $\begin{array}{l}-0.092 \\
(0.001)\end{array}$ & $\begin{array}{l}-0.056 \\
(0.066)\end{array}$ & $\begin{array}{l}-0.054 \\
(0.096)\end{array}$ \\
\hline $\begin{array}{l}\mathrm{N} \\
\mathrm{R}^{2}\end{array}$ & $\begin{array}{l}315 \\
0.10\end{array}$ & $\begin{array}{l}315 \\
0.35\end{array}$ & $\begin{array}{l}315 \\
0.34\end{array}$ & $\begin{array}{l}210 \\
0.12\end{array}$ & $\begin{array}{l}210 \\
0.59\end{array}$ & $\begin{array}{l}207 \\
0.59\end{array}$ \\
\hline
\end{tabular}




\section{Figure 1: Size and Measures of U.S. International Equity Investment}

The figure shows the relationship between float-adjusted size and two measures of U.S. international equity investment in 2001. The top graph uses a float-adjusted ratio measure of home bias, as in equation (11) similar to that in Bekaert, Siegel and Wang [2012]. The bottom graph uses a float-adjusted difference measure of home bias, as in the numerator of equation (11). Other size-biased measures of U.S. investment, such as the dollar amount, log dollar amount, or portfolio share, would be similar to the bottom graph; other measures without size biases, such as U.S. investment as a percentage of destination float, would resemble the top graph.
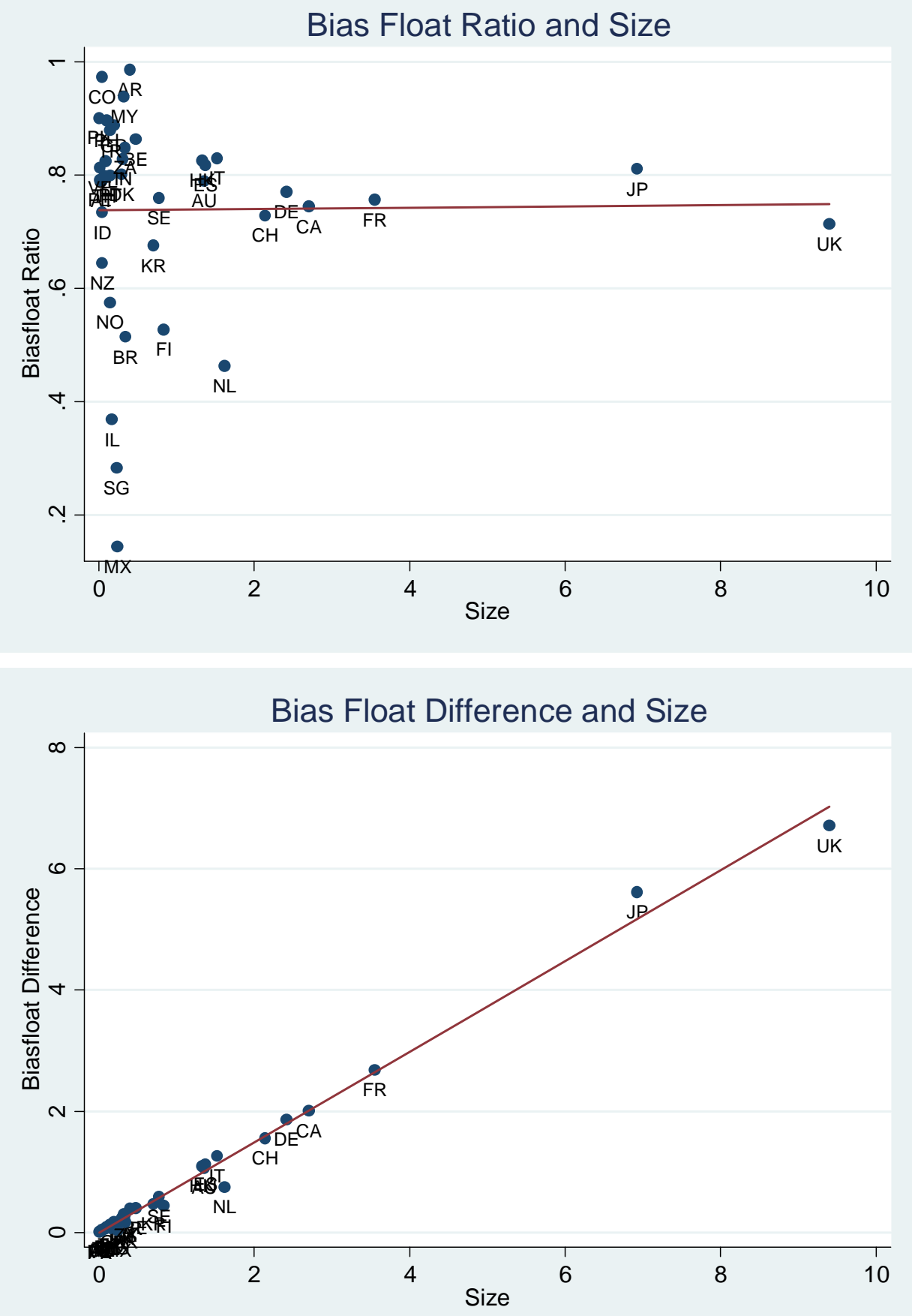


\section{Appendix A: Variables and Instruments}

\begin{tabular}{|c|c|c|}
\hline Variable & Definition & Included in: \\
\hline \multicolumn{3}{|l|}{ Firm-level variables } \\
\hline Assets relative to industry average & $\begin{array}{l}\text { Natural logarithm of the } 1997 \text { book value of a } \\
\text { firm's assets from Worldscope minus the } \\
\text { average for firms in the same Worldscope } \\
\text { Major Industry, included as the within- } \\
\text { industry part of our measure of firm size. }\end{array}$ & $\mathbf{Z}_{\mathbf{i}}^{\mathbf{x}}, \mathbf{Z}_{\mathbf{i}}^{H}$ \\
\hline $\begin{array}{l}\text { Proportion of shares held by } \\
\text { insiders }(\%)\end{array}$ & $\begin{array}{l}\text { Worldscope's } 1997 \text { value for the number of } \\
\text { closely held shares as a percentage of } \\
\text { common shares outstanding, adjusted to } \\
\text { remove those stakes mistakenly counted as } \\
\text { insider ownership by Worldscope. These } \\
\text { include holdings by the Bank of New York, } \\
\text { Morgan Guarantee Trust, and Citibank, } \\
\text { because these shares are holdings for ADR } \\
\text { programs, and the New Zealand Central } \\
\text { Securities Depository. }\end{array}$ & $\mathbf{Z}_{\mathbf{i}}^{\mathbf{X}}$ \\
\hline MSCI index member & $\begin{array}{l}\text { Dummy variable equal to one when a firm is } \\
\text { included as a member of the MSCI All- } \\
\text { country World index at the end of } 1997 \text {. }\end{array}$ & $\mathbf{Z}_{\mathbf{i}}^{H}$ \\
\hline Dividend-paying firm & $\begin{array}{l}\text { Dummy variable equal to one when a firm } \\
\text { pays a dividend in 1997, as reported by } \\
\text { Worldscope. }\end{array}$ & $\mathbf{Z}_{\mathbf{i}}^{H}$ \\
\hline Firm-level accounting quality & $\begin{array}{l}\text { Index ranging from zero to four, calculated } \\
\text { using criteria from Aggarwal, Klapper, and } \\
\text { Wysocki [2005]. Four components takes a } \\
\text { value of one if the firm (1) used a BigSix } \\
\text { auditor, (2) received a clean audit report, ( } 3) \\
\text { used international accounting standards or } \\
\text { U.S. GAAP, and (4) reported consolidated } \\
\text { statements. The index is the sum of the four } \\
\text { components. }\end{array}$ & $\mathbf{Z}_{\mathbf{i}}^{H}$ \\
\hline
\end{tabular}




\section{Appendix A (continued): Variables and Instruments.}

\begin{tabular}{|c|c|c|}
\hline Variable & Definition & Included in: \\
\hline \multicolumn{3}{|l|}{ Industry-level variables } \\
\hline $\begin{array}{l}\text { Industry-average market } \\
\text { cap }\end{array}$ & $\begin{array}{l}\text { Average natural logarithm of firms' } 1997 \\
\text { market caps for all firms in a given } \\
\text { Worldscope Major Industry, included as the } \\
\text { across-industry part of our measure of firm } \\
\text { size.. }\end{array}$ & $\mathbf{Z}_{\mathbf{i}}^{\mathbf{x}}, \mathbf{Z}_{\mathbf{i}}^{H}$ \\
\hline $\begin{array}{l}\text { Industry-level imported } \\
\text { share of U.S. supply } \\
\text { (percent) }\end{array}$ & $\begin{array}{l}\text { Matched by 2- and 4-digit SIC code to } 1992 \\
\text { data from the Bureau of the Census and the } \\
\text { Bureau of Economic Analysis, included as a } \\
\text { measure of "economic proximity" of the firm } \\
\text { to U.S. markets. }\end{array}$ & $\mathbf{Z}_{\mathbf{i}}^{\mathbf{x}}, \mathbf{Z}_{\mathbf{i}}^{H}$ \\
\hline \multicolumn{3}{|l|}{$\underline{\text { Country-level variables }}$} \\
\hline Trading volume & $\begin{array}{l}\text { Home-country trading value/GDP(\%). } 1997 \\
\text { dollar volume of trading in the home market } \\
\text { of a firm, normalized by the dollar value of } \\
\text { the country's } 1997 \text { gross domestic product } \\
\text { (GDP). The volume data are obtained from } \\
\text { the International Finance Corporation [1998] } \\
\text { and the GDP figures are collected from the } \\
\text { International Monetary Fund's International } \\
\text { Financial Statistics. }\end{array}$ & $\mathbf{Z}_{\mathbf{i}}^{\mathrm{X}}$ \\
\hline Tax Rate & $\begin{array}{l}\text { Home-country dividend withholding tax rate } \\
\text { faced by U.S. investors. For countries } \\
\text { maintaining a bilateral tax treaty with the } \\
\text { United States, we use the treaty tax rate, as } \\
\text { reported in the IRS publication } 901, \text { U.S. Tax } \\
\text { Treaties. For countries with no U.S. tax } \\
\text { treaty, we calculate dividend withholding } \\
\text { rates from } 1997 \text { gross and net dividend } \\
\text { payments to holders of ADRs, as reported in } \\
\text { Bloomberg's Corporate Action Calendar. }\end{array}$ & $\mathbf{Z}_{\mathbf{i}}^{H}$ \\
\hline Canadian firm & $\begin{array}{l}\text { Dummy variable set equal to one for } \\
\text { Canadian firms. }\end{array}$ & $\mathbf{Z}_{\mathbf{i}}^{\mathbf{x}}, \mathbf{Z}_{\mathbf{i}}^{H}$ \\
\hline Civil law & $\begin{array}{l}\text { Dummy variable set to one for firms from } \\
\text { countries using a civil law system. }\end{array}$ & $\mathbf{Z}_{\mathrm{i}}^{\mathrm{X}}$ \\
\hline
\end{tabular}




\section{Appendix A (continued): Variables and Instruments.}

\begin{tabular}{|c|c|c|}
\hline Variable & Definition & Included in: \\
\hline $\begin{array}{l}\text { National accounting quality } \\
\text { index }\end{array}$ & $\begin{array}{l}\text { Values for } 1995 \text { reported by Bushman, } \\
\text { Piotroski, and Smith [2004]. Compiled by the } \\
\text { Center for Financial Analysis and Research, } \\
\text { the index averages across firms within a given } \\
\text { country the number of items, out of a possible } \\
\text { maximum of } 90 \text {, that are included as part of a } \\
\text { firm's financial statements. }\end{array}$ & $\mathbf{Z}_{\mathbf{i}}^{\mathbf{x}}, \mathbf{Z}_{\mathbf{i}}^{H}$ \\
\hline Shareholder rights index & $\begin{array}{l}\text { Calculated by La Porta, Lopez-de-Silanes, } \\
\text { Shleifer, and Vishny [1998]. Index takes on a } \\
\text { value between } 0 \text { and } 6 \text { depending on how } \\
\text { many of the following applies to a country's } \\
\text { equity market: percentage of outstanding } \\
\text { shares required to call an extraordinary } \\
\text { meeting less than or equal to } 10 \text { percent, } \\
\text { cumulative voting or proportional } \\
\text { representation of minority interests on board, } \\
\text { voting by mail permitted, mechanisms in } \\
\text { place for oppressed minority investors, } \\
\text { preemptive right that can only be waived by a } \\
\text { shareholder vote, and protection of } \\
\text { shareholders from requirements that shares be } \\
\text { deposited before a shareholder meeting. }\end{array}$ & $\mathbf{Z}_{\mathbf{i}}^{H}$ \\
\hline
\end{tabular}


Table A1: Instrument Sample Statistics

\begin{tabular}{|c|c|c|c|c|c|c|c|c|}
\hline & \multicolumn{4}{|c|}{ Non-Cross-Listed Firms } & \multicolumn{4}{|c|}{$\underline{\text { Cross-Listed Firms }}$} \\
\hline & Min & Mean & Median & Max & Min & Mean & Median & Max \\
\hline Share Held by Insiders (\%) & 0.0 & 46.6 & 32.6 & 99.9 & 0.0 & 32.5 & 0.4 & 93.8 \\
\hline Trading volume (\% of GDP) & 2 & 62 & 34 & 449 & 2 & 52 & 60 & 449 \\
\hline Ln(Assets) minus Industry Average & -12.3 & -0.1 & -0.3 & 6.9 & -3.3 & 1.7 & 1.6 & 6.8 \\
\hline Ln(Average Industry Market Cap) & 3.6 & 4.8 & 4.8 & 6.7 & 3.7 & 5.2 & 4.9 & 6.7 \\
\hline National accounting quality & 38.0 & 73.9 & 71.6 & 85.5 & 38.0 & 75.3 & 75.2 & 85.5 \\
\hline Firm-level accounting quality & 0.0 & 2.2 & 3.0 & 4.0 & 0.0 & 2.9 & 3.0 & 4.0 \\
\hline Shareholders' anti-director rights & 0.0 & 3.6 & 4.0 & 5.0 & 0.0 & 4.0 & 5.0 & 5.0 \\
\hline Dividend withholding tax rate (\%) & 0.0 & 16.0 & 15.0 & 35.0 & 0.0 & 15.3 & 15.0 & 35.0 \\
\hline Industry-level imported share (\%) & 0.3 & 10.0 & 4.5 & 97.0 & 0.3 & 11.1 & 4.5 & 77.0 \\
\hline MSCI member (dummy) & 0.00 & 0.13 & 0.00 & 1.00 & 0.00 & 0.47 & 0.00 & 1.00 \\
\hline Dividend-paying firm (dummy) & 0.00 & 0.76 & 1.00 & 1.00 & 0.00 & 0.68 & 1.00 & 1.00 \\
\hline Canadian firm (dummy) & 0.00 & 0.03 & 0.00 & 1.00 & 0.00 & 0.29 & 0.00 & 1.00 \\
\hline Civil law (dummy) & 0.00 & 0.61 & 1.00 & 1.00 & 0.00 & 0.42 & 0.00 & 1.00 \\
\hline
\end{tabular}




\section{Appendix B: Estimating the Structural Model}

Lee [1978] proposes a multi-stage method for consistently estimating a system like ours in which a first-stage, reduced-form probit generates Heckman [1979]-type correction terms for the holdings equations. The corrected second-stage estimation of the holdings equations produces consistent estimates of the relation between the instruments and holdings, and makes it possible to calculate fitted holdings values as a function of the instruments. The final stage of estimation involves using the fitted holdings for estimation of the structural probit in equation (7).

To facilitate implementation of the Lee [1978] estimation framework, we assume that the joint statistical distribution of the residuals in the listing equation $\left(\varepsilon_{\mathrm{i}}^{\mathrm{X}}\right)$ and the two holdings equations $\left(\varepsilon_{\mathrm{i}}^{\mathrm{L}}, \varepsilon_{\mathrm{i}}^{\mathrm{U}}\right)$ are jointly normally distributed,

$$
\left(\varepsilon_{\mathrm{i}}^{\mathrm{X}}, \varepsilon_{\mathrm{i}}^{\mathrm{L}}, \varepsilon_{\mathrm{i}}^{\mathrm{U}}\right) \sim \mathrm{N}(0, \Omega),
$$

where $\Omega$ is a $3 \times 3$ variance covariance matrix.

Lee [1978] has shown that multi-stage estimation will produce estimates of structural parameters that are consistent in the presence of selection bias.

One advantage of this framework is that although we only observe $\mathrm{H}_{\mathrm{i}}^{\mathrm{L}}$ for firms that have a U.S. listing and $\mathrm{H}_{\mathrm{i}}^{\mathrm{U}}$ for firms that do not, we can use our parameter estimates to make inferences about what U.S. holdings of a firm's stock would have been had the firm made the counterfactual choice about whether to cross-list. Furthermore, we can generate estimates of the cross-listing effect-i.e., the impact of crosslisting on U.S. holdings $\left(\mathrm{H}_{\mathrm{i}}^{\mathrm{L}}-\mathrm{H}_{\mathrm{i}}^{\mathrm{U}}\right)$ - either unconditionally or conditional on specific firm characteristics.

In the first stage of the Lee [1978] methodology, the two holdings equations are substituted into the listing probit to form a reduced-form listing equation that can be estimated on a stand-alone basis by numerical maximum likelihood. The set of independent variables $\left(\mathbf{Z}^{\mathbf{R}}\right)$ for the first-stage reduced-form probit specification consists of all of the instruments in the structural equations for listing and holdings:

$$
\mathbf{Z}^{\mathbf{R}}=\mathbf{Z}^{\mathbf{X}} \cup \mathbf{Z}^{H}
$$

We can write the first-stage equation as

$$
X_{i}^{*}=\alpha_{R}+Z_{i}^{R} \beta_{R}-\varepsilon_{i}^{R},
$$

where

$$
\varepsilon_{i}^{R}=\gamma_{0} \varepsilon_{i}^{L}+Z_{i}^{R}\left(\gamma_{0}-\gamma_{1}\right) \varepsilon_{i}^{U}+\varepsilon_{i}^{X} .
$$

The estimates from the probit model embodied in equations (B-2), (B-3), and (B-4) can be used to construct the selectivity-bias correction in the holdings-equations residuals $\left(\varepsilon^{\mathrm{L}}\right.$ and $\left.\varepsilon^{\mathrm{U}}\right)$. It can be shown that for listed firms $\left(\mathrm{X}^{*}=0\right)$,

$$
\mathrm{E}\left(\varepsilon_{\mathrm{i}}^{\mathrm{L}} \mid \mathrm{X}^{*} \geq 0\right)=-\operatorname{cov}\left(\varepsilon_{\mathrm{i}}^{\mathrm{X}}, \varepsilon_{\mathrm{i}}^{\mathrm{L}}\right) \frac{\phi\left(\alpha_{\mathrm{R}}+\mathrm{Z}_{\mathrm{i}}^{\mathrm{R}} \beta_{\mathrm{R}}\right)}{\Phi\left(\alpha_{\mathrm{R}}+Z_{\mathrm{i}}^{\mathrm{R}} \beta_{\mathrm{R}}\right)},
$$

where the variance of $\varepsilon^{\mathrm{X}}$ has been normalized to one and $\phi$ and $\Phi$ denote the probability density function and cumulative density function, respectively, of the standard normal distribution. The ratio 


$$
\frac{\phi\left(\alpha_{R}+Z_{i}^{R} \beta_{R}\right)}{\Phi\left(\alpha_{R}+Z_{i}^{R} \beta_{R}\right)}
$$

is often referred to as the "inverse Mills ratio". Estimates of the ratio form the basis for standard corrections for selectivity bias when inclusion in an estimation sample is contingent on a discrete outcome (see Heckman [1979] or Maddala [1983]). Intuitively, the inverse Mills ratio accounts for the unobserved correlation between the listing decision and holdings. There is also a similar, but less frequently used correction for selectivity bias for the non-selected observations,

$$
\mathrm{E}\left(\varepsilon_{\mathrm{i}}^{\mathrm{U}} \mid \mathrm{X}^{*}<0\right)=\operatorname{cov}\left(\varepsilon_{\mathrm{i}}^{\mathrm{X}}, \varepsilon_{\mathrm{i}}^{\mathrm{U}}\right) \frac{\phi\left(\alpha_{\mathrm{R}}+\mathrm{Z}_{\mathrm{i}}^{\mathrm{R}} \beta_{\mathrm{R}}\right)}{1-\Phi\left(\alpha_{\mathrm{R}}+\mathrm{Z}_{\mathrm{i}}^{\mathrm{R}} \beta_{\mathrm{R}}\right)} .
$$

The second stage of the Lee procedure involves estimating the holdings equations by ordinary least squares by rewriting them as

$$
H_{i}^{L}=\alpha_{L}+Z_{i}^{H} \beta_{L}-\frac{\varphi\left(\alpha_{R}+Z_{i}^{R} \beta_{R}\right)}{\Phi\left(\alpha_{R}+Z_{i}^{R} \beta_{R}\right)} \lambda_{L}+\eta_{i}^{L}
$$

and

$$
H_{i}^{U}=\alpha_{U}+Z_{i}^{H} \beta_{U}+\frac{\varphi\left(\alpha_{R}+Z_{i}^{R} \beta_{R}\right)}{1-\Phi\left(\alpha_{R}+Z_{i}^{R} \beta_{R}\right)} \lambda_{U}+\eta_{i}^{U}
$$

Note that $\lambda_{k}=\operatorname{cov}\left(\varepsilon_{i}^{X}, \varepsilon_{i}^{k}\right)$ for $\mathrm{k}=\mathrm{L}, \mathrm{U}$ and $\mathrm{E}\left(\eta_{\mathrm{i}}^{\mathrm{L}} \mid \mathrm{X}^{*} \geq 0\right)=\mathrm{E}\left(\eta_{\mathrm{i}}^{\mathrm{U}} \mid \mathrm{X}^{*}<0\right)=0$. We use our first-stage estimates of the parameters $\alpha_{R}$ and $\beta_{R}$ to construct the selectivity variables, and then substitute these variables into equations (B-8) and (B-9). The coefficient associated with the selectivity adjustment provides an estimate of the unobserved covariance between the listing decision and each of the holding equations. The final stage of the Lee procedure involves using the consistent estimates of $\alpha_{L}, \alpha_{U}, \beta_{L}$, and $\beta_{U}$ from (B-8) and (B-9) to construct fitted values using the original holdings equations. The fitted holdings are inserted back into the structural listing decision equation, which is then estimated as a probit model via numerical likelihood maximization. As noted by Lee [1978], it is possible to construct consistent standard errors for the holdings equations after making a correction for heteroscedasticity associated with the selectivity terms.

Because the estimated parameters of the model are difficult to interpret, we rescale the estimates to show the marginal effect of a one-unit change in the instrument on the percentage point probability of cross-listing, specifically the median effect over the firms in the sample. 